\title{
Understanding the conformational changes and molecular structure of furoyl thioureas upon substitution
}

\author{
Raúl Ramos Cairo a , Ana María Plutín Stevens ${ }^{\mathrm{a}, *}$, Tamires Donizeth de Oliveira ${ }^{\mathrm{b}}$, Alzir A. Batista ${ }^{\mathrm{b}}$, \\ Eduardo E. Castellano ${ }^{\text {c }}$, Julio Duque ${ }^{\text {d }}$, Delia B. Soria ${ }^{\text {e }}$, Adolfo C. Fantoni ${ }^{\text {f }}$, \\ Rodrigo S. Corrêa ${ }^{g}$, Mauricio F. Erben ${ }^{\mathrm{e}, *}$ \\ a Laboratorio de Síntesis Orgánica, Facultad de Química, Universidad de La Habana, La Habana, Cuba

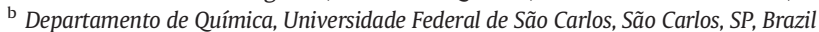 \\ c Instituto de Química de São Carlos, Universidade de São Paulo, São Carlos, SP, Brazil \\ 'Instituto de Ciencia y Tecnología de Materiales (IMRE), Universidad de La Habana, Havana, Cuba \\ e CEQUINOR (UNLP-CONICET, CCT La Plata), Departamento de Química, Facultad de Ciencias Exactas, Universidad Nacional de La Plata, C.C. 962 (1900), La Plata, Argentina \\ ${ }^{\mathrm{f}}$ Instituto de Física La Plata, Departamento de Física, Facultad de Ciencias Exactas, Universidad Nacional de La Plata, 49 y 115, La Plata, Buenos Aires, Argentina \\ ${ }^{g}$ Departamento de Química (DeQui), Instituto de Ciências Exatas e Biológicas, Universidade Federal de Ouro Preto - UFOP, Ouro Preto, Brazil
}

\section{A R T I C L E I N F O}

\section{Article history:}

Received 26 October 2016

Received in revised form 16 December 2016

Accepted 24 December 2016

Available online 28 December 2016

\section{Keywords:}

Thiourea derivatives

Molecular conformation

Single crystal structure determination

Vibrational spectroscopy

Hirshfeld surface analysis

Topological study

\begin{abstract}
A B S T R A C T
1-Acyl thioureas $\left[R^{1} C(O) N H C(S) N R^{2} R^{3}\right]$ are shown to display conformational flexibility depending on the degree of substitution at the nitrogen atom. The conformational landscape and structural features for two closely related thioureas having $\mathrm{R}^{1}=2$-furoyl have been studied. The un-substituted 2-furoyl thiourea (I) and its dimethyl analogue, i.e. 1-(2-furoyl)-3,3-dimethyl thiourea (II), have been synthesized and fully characterized by spectroscopic (FT-IR, ${ }^{1} \mathrm{H}$ and ${ }^{13} \mathrm{C}$ NMR) and elemental analysis. According to single crystal X-ray diffraction analysis, compounds I and II crystallize in the monoclinic space group P21/c. In the compound I, the trans-cis geometry of the almost planar thiourea unit is stabilized by intramolecular $\mathrm{N}-\mathrm{H} \cdots \mathrm{O}=\mathrm{C}$ hydrogen bond between the $\mathrm{H}$ atom of the cis thioamide and the carbonyl $\mathrm{O}$ atom. In compound II, however, the acyl thiourea group is non-planar, in good agreement with the potential energy curve computed at the B3LYP/6-31 + G(d,p) level of approximation. Centrosymmetric dimers generated by intermolecular $\mathrm{N}-\mathrm{H} \cdots \mathrm{S}=\mathrm{C}$ hydrogen bond forming $\mathrm{R}_{2}^{2}(8)$ motif are present in the crystals. Intermolecular interactions have been rationalized in terms of topological partitions of the electron distributions and Hirshfeld surface analysis, which showed the occurrence of $\mathrm{S} \cdots \mathrm{H}, \mathrm{O} \cdots \mathrm{H}$ and $\mathrm{H} \cdots \mathrm{H}$ contacts that display an important role to crystal packing stabilization of both thiourea derivatives.
\end{abstract}

(c) 2016 Published by Elsevier B.V.

\section{Introduction}

1-Acyl thiourea derivatives, with general formula $R^{1} C(O) N H C(S) N R^{2} R^{3}$, are versatile compounds that have attracted much attention in many fields, such as chemical intermediates in synthesis, biological and pharmaceutical chemistry, and as promising new materials in environmental applications. Comprehensive review articles can be found in the recent literature covering the chemistry, structure and applications of these compounds [1-4].

It has been determined that desired properties depend on the structure and conformation adopted by the central 1-acyl thiourea group. The interplay between intermolecular and intramolecular hydrogen bonding greatly affects the chemical properties of these compounds, including their use as ligand in metal complexes [1], as reagents in

\footnotetext{
* Corresponding authors.

E-mail addresses: anap@quimica.uh.cu (A.M.P. Stevens), erben@quimica.unlp.edu.ar (M.F. Erben).
}

cyclization reactions [4], biological activities and other useful applications. In particular, a ligand-based structural optimization methodology for the preparation of a series of 1-(acyl)-3-(mono) and 1-(acyl)-3,3(di) substituted thioureas has been developed, with potent smoothened antagonist [5]. Interestingly, a series of analogous acylureas or acylguanidines compounds displayed similar biological activities [6,7]. From this similitude, the existence of common hydrogen-bonding interactions between the ligands and the receptor pocket was proposed [6]. Similarly, the hydrogen-bonding ability of 1-(acyl)-3-(mono) substituted thioureas make these molecules candidates for anion receptors [8-10].

Hydrogen bonds also influence the conformational equilibria around the 1-acyl thiourea core. In effect, several conformations are possible for these compounds, depending on the orientations adopted by the $\mathrm{C}=0$ and $\mathrm{C}=\mathrm{S}$ double bonds with respect to the $\mathrm{C}-\mathrm{N}$ bonds [11-13]. Following Woldu and Dillen [14], the two main forms are denote as $S$ and $U$ (the letter reflects the position of the $\mathrm{C}=\mathrm{O}$ and $\mathrm{C}=\mathrm{S}$ double bonds relative to the vertically drawn $\mathrm{N}-\mathrm{H}$ bond, as shown in Scheme 1). As 
<smiles>[R]NC(=S)NC([R])=O</smiles>

$S$<smiles>[R]C(=O)N([2H])C(=S)N([R])[Y]</smiles>

$U$
Scheme 1. Main conformations observed for 3-mono ( $S$ form) and 3,3-di substituted ( $U$ form) 1-acyl thioureas.

reported by Becker and coworkers [15], the $S$ form prevails for 1-(acyl/ aroyl)-3-(mono-substituted) thiourea derivatives with $\mathrm{R}^{2}=\mathrm{H}$, because the formation of intramolecular $\mathrm{C}=\mathrm{O} \cdots \mathrm{H}-\mathrm{N}$ hydrogen bond strongly stabilize this conformation [16-18]. On the other hand, 1-(acyl/aroyl)3,3-(di-substituted) thioureas tend to adopt the $U$ form since in this case $R^{2}$ and $R^{3} \neq H$ and thus, the formation of a intramolecular hydrogen bond is disallowed [19].

Thiourea derivatives containing the 2-furoyl group were synthesized [20-24] and the complexation ability of these ligands toward various metal ions was investigated [25-28], with salient analytical applications [29]. In particular, 1-(2-furoyl)-3-substituted thioureas were probed as useful intermediates used in environmental control and as ionophores in ion selective electrodes [26,30]. Recently, mesoporous silica hybrid materials functionalized with 1-(2-furoyl) thioureas exhibited good ability to remove $\mathrm{Hg}$ (II) from aqueous solutions [31].

In this article the effect of substitution at the 2-furoyl thiourea core is analyzed by studying two closely related species, i.e. the "parent" and the novel 3,3-dimethylated thioureas (compounds I and II in Scheme 2, respectively). Structural characterization includes experimental spectroscopic (FT-IR and Raman) and X-ray diffraction studies, complemented with a detailed analysis of intermolecular interactions by Hirshfeld surfaces and Atom in Molecule (AIM) topological analysis of the electron charge density.

\section{Experimental}

\subsection{Material and Measurements}

Thin layer chromatography (TLC) was performed on $0.25 \mathrm{~mm}$ silica gel pre-coated plastic sheets $(40 / 80 \mathrm{~mm}$ ) (Polygram SIL G/UV254, Macherey \& Nagel, Düren, Germany) using benzene/methanol (9/1) as eluent. The IR spectra were recorded on a FT-IR Bomem-Michelson 102 spectrometer, in $\mathrm{KBr}$ pellets with a resolution of $2 \mathrm{~cm}^{-1}$ in the $4000-400 \mathrm{~cm}^{-1}$ range. Raman spectra for compounds I and II were recorded using a Horiba Jobin Yvon T64000 Raman spectrometer equipped with a liquid $\mathrm{N}_{2}$-cooled back-thinned CCD detector. Spectra were recorded as the co-addition of up to 16 individual spectra with CCD exposure times of $10-20 \mathrm{~s}$ each. ${ }^{1} \mathrm{H}$ and ${ }^{13} \mathrm{C}$ NMR spectra were recorded on a Bruker DRX $400 \mathrm{MHz}$, internally referenced to TMS,

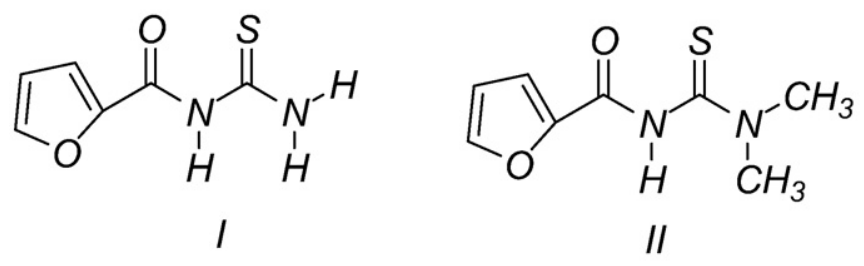

Scheme 2. 1-(2-furoyl) thioureas I and II studied in this work. chemical shift $(\delta)$, multiplicity ( $m$ ), spin-spin coupling constant $(J)$, integral (I) are given. $\mathrm{CDCl}_{3}$ was used as solvent. Partial elemental analyses were carried out in an instrument of CHNS staff EA 1108 of the FISONS. Thermal analyses were performed with Shimadzu TGA-50 unit, between room temperature and $750{ }^{\circ} \mathrm{C}$, at a heating rate of $5{ }^{\circ} \mathrm{C} /$ min and nitrogen flow of $50 \mathrm{~mL} / \mathrm{min}$.

\subsection{Quantum Chemical Calculations}

Optimization of molecular geometries was accomplished within the frame work of the density functional theory [32,33] as implemented in the Gaussian 03 package [34]. Contracted Gaussian basis sets of triplezeta quality plus polarized and diffuse functions $6-311++G(d, p)$ for all atoms were used throughout the present work [35]. The corresponding vibrational analyses were performed for the optimized geometries (Cartesian coordinates are given in Tables S1 and S2 in the Supporting information) to verify whether they are local minima or saddle points on the potential energy surface of the molecule. Calculated normal modes were also used as an aid in the assignment of experimental frequencies. Natural Bond Orbital (NBO) population analysis were performed and the energy of the donor-acceptor interactions estimated by the second order perturbation theory [36].

Periodic calculations were performed at the B3LYP/6-31G(d,p) level with Crystal14 code [37]. Using the experimental estimations as the starting point, the coordinates of the hydrogen atoms in the crystal were optimized to minimize the crystal energy with heavy atom coordinates and cell parameters fixed at their experimental values. The topology of the resulting electron density was then analyzed using the TOPOND14 code $[38,39]$.

\subsection{Synthesis of 2-Furoyl Thioureas}

Detailed descriptions of syntheses and characterization of related furoyl thioureas have been previously reported [13]. A solution of an appropriately acyl chloride ( $30 \mathrm{mmol}$ ) in acetone $(50 \mathrm{~mL}$ ) was added drop wise to a suspension of $\mathrm{KSCN}(30 \mathrm{mmol})$ in acetone $(30 \mathrm{~mL})$. The mixture was stirred until a precipitate appeared $(\mathrm{KCl})$, indicating the formation of 2-furoyl isothiocyanate. Ammonia [31] or dimethyl amine (30 mmol), dissolved in acetone was slowly added with constant stirring of the resulting solution (Scheme 3). The solution was cooled in an ice-water bath and the stirring was continued at room temperature during 2-9 h, until the reaction was completed (the reaction progress was monitored by TLC). The reaction mixture was then poured into $600 \mathrm{~mL}$ of cold water. The solid thioureas were collected by filtration and finally purified by re-crystallization from acetone:water mixture. The identity of the products was confirmed by the analysis of the ${ }^{1} \mathrm{H}$ and ${ }^{13} \mathrm{C}$ NMR spectra (given in Figs. S1-S4 of the Supplementary information) in comparison to similar compounds previously reported in the literature [13].

2-Furoyl thiourea (I): yield 79\%, mp $146-147^{\circ} \mathrm{C}$. FT-IR [ATR (solid), $\nu \cdot \mathrm{cm}^{-1}$ ]: 3336, 3320, 3302, 3000, 1679, 1606, 1529, 1350, 1178, 883, 756. ${ }^{1} \mathrm{H}$ NMR (400 MHz, DMSO- $d_{6}$ ): 10.92 (s, $1 \mathrm{H}, \mathrm{NH}, \mathrm{D}_{2} \mathrm{O}$ exchangeable); 9.58 (s, $1 \mathrm{H}, \mathrm{NH}, \mathrm{D}_{2} \mathrm{O}$ exchangeable); 8.02 (dd, $2 \mathrm{H}, J=2.6 \mathrm{~Hz}$ Ar), 7.79 (dd), 6.73 (dd,). ${ }^{13} \mathrm{C}$ NMR (400 MHz, DMSO-d $\left.d_{6}\right): 181.5$ $(\mathrm{C}=\mathrm{S}) ; 157.1(\mathrm{C}=0), 148.1,144.7,118.2$ and 112.5 . Anal. Calc. for $\mathrm{C}_{6} \mathrm{H}_{6} \mathrm{~N}_{2} \mathrm{O}_{2} \mathrm{~S}$ (170.01): C, 42.34; H, 3.55; N, 6.46; S, 8.84\%; Found: C, 42.00; H, 3.50; N, 5.90; S, 8.90\%.

1-(2-furoyl)-3,3-dimethyl thiourea (II): yield $82 \%$, mp $146-147^{\circ} \mathrm{C}$. FT-IR [ATR (solid), $\nu \cdot \mathrm{cm}^{-1}$ ]: 3161, 2923, 1697, 1571, 1473, 1263, 1178, 929, 761. ${ }^{1} \mathrm{H}$ NMR (400 MHz, $\mathrm{CDCl}_{3}$ ): 8.63 (s, ${ }^{1} \mathrm{H}, \mathrm{NH}, \mathrm{D}_{2} \mathrm{O}$ exchangeable); $7.56(\mathrm{dd}), 7.27(\mathrm{dd}), 6.58(\mathrm{dd}), 3.40\left(\mathrm{~s}, \mathrm{CH}_{3}\right)$ and $3.28(\mathrm{~s}$, $\left.\mathrm{CH}_{3}\right) .{ }^{13} \mathrm{C}$ NMR (400 MHz, $\left.\mathrm{CDCl}_{3}\right)$ : $179.0(\mathrm{C}=\mathrm{S}) ; 153.4(\mathrm{C}=0), 146.1$, 145.5, 117.3, 112.8. Anal. Calc. for $\mathrm{C}_{8} \mathrm{H}_{10} \mathrm{~N}_{2} \mathrm{O}_{2} \mathrm{~S}$ (198.05): C, 48.47; $\mathrm{H}$, 5.08; N, 4.13; S, 8.17\%; Found: C, 48.00; H, 5.30; N, 4.50; S, 8.50\%. 


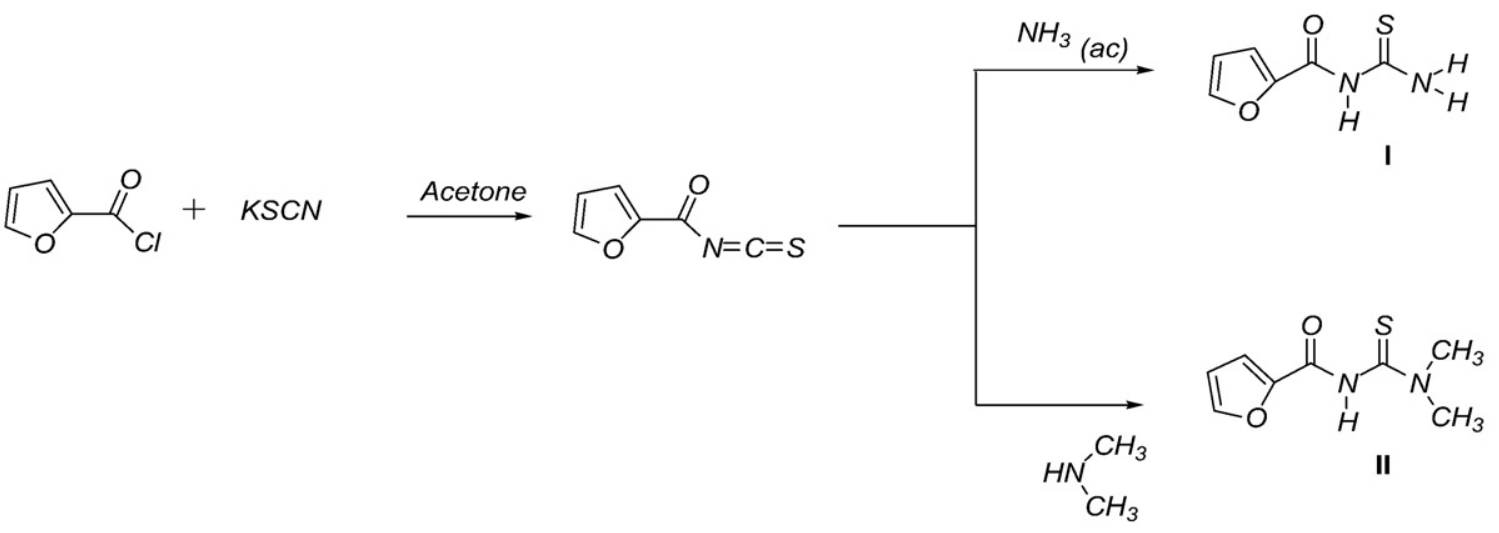

Scheme 3. Synthesis of 2-furoyl thioureas I and II.

\subsection{Crystal Structure Determination}

Single crystals suitable for X-ray diffraction were obtained by slow evaporation of $\mathrm{CHCl}_{3}: n$-hexane (3:1) solutions of the furoyl thioureas I and II. Diffraction data were collected on an Enraf-Nonius Kappa-CCD diffractometer with graphite-monochromated MoK $\alpha$ radiation $(\lambda=$ $0.71073 \AA$ A). The final unit cell parameters were based on all reflections. Data collections were performed using the COLLECT program [40], integration and scaling of the reflections were performed with the HKL Denzo-Scalepack system of programs [41]. Absorption corrections were carried out using the Gaussian method [42]. The structures were solved by direct methods with SHELXS-97 [43]. The models were refined by full-matrix least-squares on $\mathrm{F}^{2}$ by means of SHELXL-97. The projection views of the structures were prepared using ORTEP-3 for Windows [44]. Hydrogen atoms were stereochemically positioned and refined with the riding model. The crystal and refinement data for title compounds are listed in Table 1 with the CCDC deposit numbers for supplementary crystallographic data.

Table 1

Crystal data and refinement parameters for compounds I and II.

\begin{tabular}{|c|c|c|}
\hline Compound & I & II \\
\hline Empirical formula & $\mathrm{C}_{6} \mathrm{H}_{6} \mathrm{~N}_{2} \mathrm{O}_{2} \mathrm{~S}$ & $\mathrm{C}_{8} \mathrm{H}_{10} \mathrm{~N}_{2} \mathrm{O}_{2} \mathrm{~S}$ \\
\hline Formula weight & 170.19 & 198.24 \\
\hline Crystal system & Monoclinic & Monoclinic \\
\hline Space group & $\mathrm{P} 2_{1} / \mathrm{c}$ & $\mathrm{P} 2_{1} / \mathrm{c}$ \\
\hline \multicolumn{3}{|l|}{ Unit cell dimensions $\left(\AA ;^{\circ}\right)$} \\
\hline$a(\AA)$ & $9.3851(6)$ & $4.97290(10)$ \\
\hline$b(\AA)$ & $7.3711(5)$ & $10.7065(5)$ \\
\hline$c(\AA)$ & $10.6129(5)$ & $17.7566(7)$ \\
\hline$\beta\left({ }^{\circ}\right)$ & $95.038(4)$ & $94.568(2)$ \\
\hline Volume $\left(\AA^{3}\right)$ & $731.35(8)$ & $942.40(6)$ \\
\hline $\mathrm{Z}$ & 4 & 4 \\
\hline Density calc $\left(\mathrm{mg} / \mathrm{m}^{3}\right)$ & 1.546 & 1.397 \\
\hline Absorption coefficient $\left(\mathrm{mm}^{-1}\right)$ & 2.998 & 0.312 \\
\hline $\mathrm{F}(000)$ & 352 & 416 \\
\hline$\theta$ range for data collection $\left({ }^{\circ}\right)$ & 3.37 to 25.97 & 2.986 to 25.996 \\
\hline \multirow[t]{3}{*}{ Index ranges } & $-11 \leq \mathrm{h} \leq 11$ & $-6 \leq \mathrm{h} \leq 5$ \\
\hline & $-8 \leq \mathrm{k} \leq 9$ & $-13 \leq \mathrm{k} \leq 12$ \\
\hline & $-13 \leq 1 \leq 12$ & $-21 \leq 1 \leq 19$ \\
\hline Reflections collected & 4544 & 6464 \\
\hline \multirow[t]{2}{*}{ Independent reflections $\left(R_{\text {int }}\right)$} & 1419 & 1835 \\
\hline & {$[\mathrm{R}($ int $)=0.0351]$} & {$[\mathrm{R}($ int $)=0.0414]$} \\
\hline Goodness-of-fit on $\mathrm{F}^{2}$ & 1.071 & 1.313 \\
\hline $\mathrm{R} 1[\mathrm{I}>2 \sigma(\mathrm{I})]$ & $\mathrm{R} 1=0.0411$ & $\mathrm{R} 1=0.0336$ \\
\hline $\mathrm{wR} 2[\mathrm{I}>2 \sigma(\mathrm{I})]$ & $\mathrm{wR} 2=0.1064$ & $\mathrm{wR2}=0.0734$ \\
\hline Largest diff. peak and hole $\left(\mathrm{e}^{-3}\right)$ & 0.251 and -0.309 & 0.294 and -0.326 \\
\hline CCDC deposit number & 931,558 & $1,502,060$ \\
\hline
\end{tabular}

\section{Results and Discussion}

\subsection{Synthesis and Characterization}

2-Furoyl thioureas I and II were synthesized according to the general method early reported by Douglass and Dains [45] and further optimized for 2-furoyl substitutions [13,31]. The one-pot procedure involves the in situ reaction between 2-furoyl chloride and KSCN and the reaction of the intermediate 2-furoyl isothiocyanate with the appropriated amine. The reaction proceeds via a nucleophilic addition of the amine to the isothiocyanate with good yields ( 79 and $82 \%$, for I and II, respectively). The synthesized compounds were purified by recrystallization from an acetone:water mixture (1:2) and characterized by elemental analysis, ${ }^{1} \mathrm{H}$ NMR, ${ }^{13} \mathrm{CNMR}$, and FT-IR spectroscopy. In ${ }^{1} \mathrm{H}$ NMR, the compounds exhibited broad signals in the range of 10.92, 9.58 and $8.63 \mathrm{ppm}$, which were assigned to the $\mathrm{N}-\mathrm{H}$ protons. ${ }^{13} \mathrm{C}$ NMR spectrum showed the peaks at about $\delta 181.5$ and 179.0 for $\mathrm{C}=\mathrm{S}$ (thioamide) and 157.1 and 153.4 for $C=0$ (amide), respectively. The elemental analyses closely corresponded to calculated values.

\subsection{Vibrational Spectra}

Infrared and Raman spectroscopies have shown to be very useful for analyzing the conformational properties, as well as intermolecular and intramolecular hydrogen bond interactions involving $\mathrm{N}-\mathrm{H}$ donors of acyl thioureas [11,46-54]. As early noted by Reguera et al. [21] the joint analysis of both infrared and Raman spectroscopy are required for study the effect on the substitution for a series of mono- and disubstituted thioureas. Recently, we have shown the complementarily of both techniques for the analysis of 1-(adamantane-1-carbonyl)-3(mono)- and 3,3-(di) substituted thioureas [55]. The $3 \mathrm{~N}-6=45$ normal modes of vibration for compound I can be classified as $31 \mathrm{~A}^{\prime}$ inplane modes and $14 \mathrm{~A}^{\prime \prime}$ out-of-plane modes in the $\mathrm{C}_{\mathrm{S}}$ symmetry group.

In particular, the $1720-1050 \mathrm{~cm}^{-1}$ region of the Raman spectrum of compounds I and II is shown in Fig. 1. The close examination of the $\nu(\mathrm{C}=\mathrm{O})$ stretching mode region reveals a strong absorption at $1679 \mathrm{~cm}^{-1}$, with a counterpart in the Raman spectrum at $1680 \mathrm{~cm}^{-1}$ for compound I, whereas this mode appears shifted toward higher frequencies for compound II, with values at $1697 \mathrm{~cm}^{-1}$ (IR) and $1693 \mathrm{~cm}^{-1}$ (Raman), as shown in Fig. 1. These values are in good agreement with those previously reported for related acyl thioureas and 1acyl-3,3-di-substituted thioureas [56]. The experimental values are well-reproduced by the quantum chemical calculations, with computed $\nu(\mathrm{C}=0)$ frequency values of 1735 and $1760 \mathrm{~cm}^{-1}$ for I ( $\mathrm{A}^{\prime}$ symmetry species) and II, respectively. The lower force constant of the $\nu(C=0)$ stretching found for compound $\mathbf{I}$ is associated with the intramolecular $\mathrm{N}-\mathrm{H} \cdots \mathrm{O}=\mathrm{C}$ hydrogen bond. 


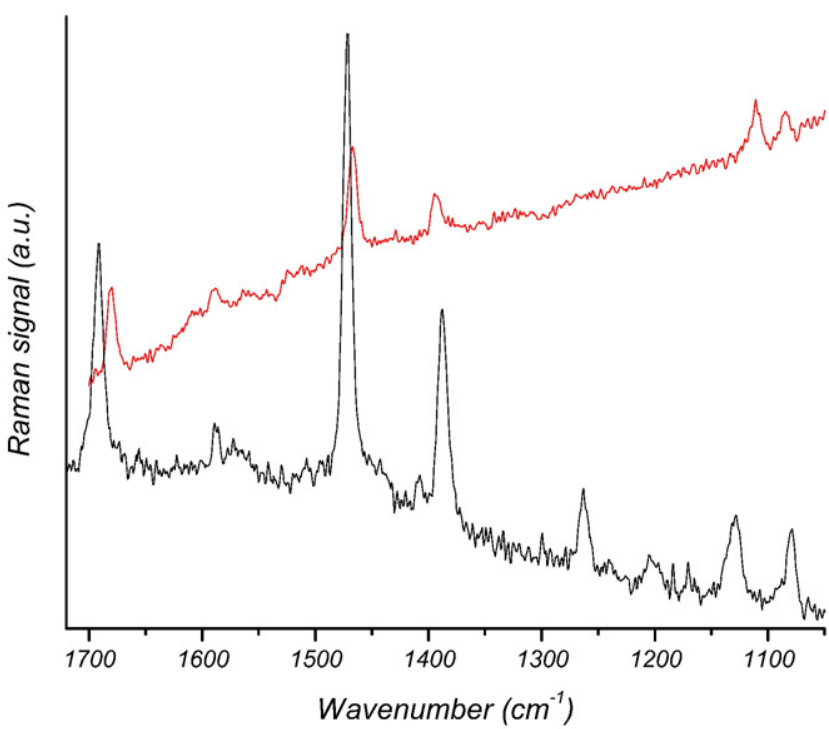

Fig. 1. Selected region of the Raman spectra for the solid phase of compounds I and II.

Intense absorptions in the $1500-1600 \mathrm{~cm}^{-1}$ region due to the $\delta(\mathrm{N}-\mathrm{H})$ deformation modes are usually observed in the infrared and Raman spectra of thioureas [57], whereas only one $\delta(\mathrm{N}-\mathrm{H})$ band is expected for the 3,3-disubstituted species. The infrared spectra show very strong and rather broad absorptions at around $1559\left(1579 \mathrm{~cm}^{-1}\right.$ Raman) and $1571 \mathrm{~cm}^{-1}$ (1587 $\mathrm{cm}^{-1}$ Raman) for I and II, respectively, in agreement with previous works [58].

The $\nu(\mathrm{C}=\mathrm{S})$ stretching mode of 1-acyl thiourea compounds is sensitive to the presence of intermolecular interactions involving the $\mathrm{C}=\mathrm{S}$ group [46] and it is found in the $600-800 \mathrm{~cm}^{-1}$ range $[21,25,59,60]$. In accordance with the computed vibrational data, we assigned this mode to the absorptions observed at 756 and $761 \mathrm{~cm}^{-1}$, with counterparts in the Raman spectra at 753 and $755 \mathrm{~cm}^{-1}$, for compounds I ( $\mathrm{A}^{\prime}$ symmetry species) and II, respectively.

\subsection{Thermal Analysis}

In order to know the thermal stability of the two compounds, the thermogravimetric study (TG) was carried out. The analysis of TG curves indicates that both compounds point toward a similar thermal behavior over the temperature range of $100-750{ }^{\circ} \mathrm{C}$, as shown in Fig. 2. Further it can be seen that nearly the total decomposition occur between the temperature range from 100 to $300^{\circ} \mathrm{C}$ in both compounds. Compound I decomposes at slightly higher temperature than compound II. This thermal stability is in agreement with the nearly planar structure in I, favors in this way the donor $\rightarrow$ acceptor interactions

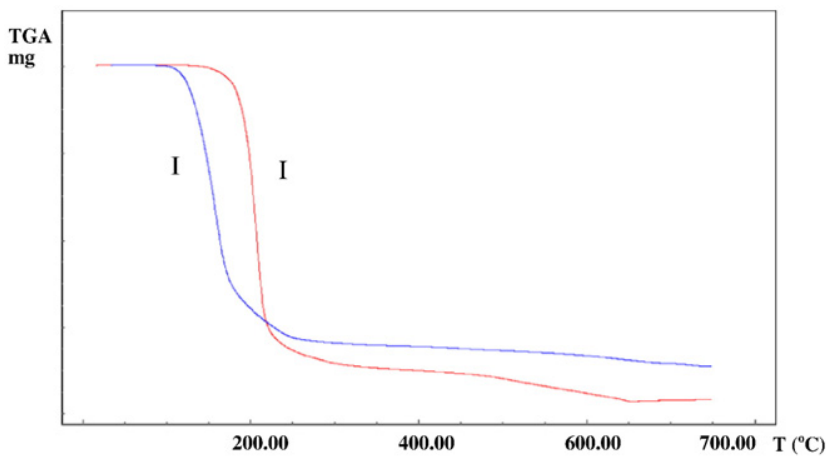

Fig. 2. TGs curves for compounds I (red) and II (blue). through the intramolecular, $\mathrm{N}-\mathrm{H} \cdots \mathrm{O}=\mathrm{C}$, hydrogen bonds, as will be discussed below. The first step observed in the TG curve for compound I with a loss mass of $88.54 \%$, is consistent with the removal (fragmentation) of furoyl $\mathrm{C}(\mathrm{O}) \mathrm{NC}(\mathrm{S})$ moiety (calculated loss weight of $89.90 \%)$. The second step observed in the TG curve with a loss mass of $9.76 \%$, is probably due to the formation of $\mathrm{NH}_{3}$ as a result of a mechanisms simultaneous by a migrating of the $\mathrm{NH}$ hydrogen atoms and the cleavage (homolysis) of $\mathrm{C}-\mathrm{N}$ bonds (loss of weight calculated 9.98\%). This thermal fragmentation mechanism is in agreement with that suggested previously in the pyrolysis of related furoyl thioureas studied by mass spectrometry methods $[61,62]$.

\subsection{Molecular Structure}

\subsubsection{Theoretical Conformational and Natural Bond Orbital Analysis}

A rich conformational landscape can be anticipated for the studied compounds. In particular, several conformations can be adopted depending on the relative orientation of the $\mathrm{C}=\mathrm{O}$ and $\mathrm{C}=\mathrm{S}$ double bonds of the acyl thiourea core. Based on previous reports $[11,12]$ the most relevant conformational changes are expected by differences in the relative orientations around the $\mathrm{C}-\mathrm{N}$ bond joining the amide and thioamide groups [18]. The potential energy curve around the $\mathrm{C}-\mathrm{N}$ bond for compounds I and II have been computed at the B3LYP/6$31+\mathrm{G}(\mathrm{d}, \mathrm{p})$ level of approximation, allowing geometry optimizations with the $\delta(\mathrm{CN}-\mathrm{CN})$ dihedral angle varying from 0 to $360^{\circ}$ in steps of $20^{\circ}$ (Fig. 3). For compound $\mathbf{I}$, the most stable structure corresponds to the $S$ form (see Scheme 1 ) with a dihedral angle of $0^{\circ}$. In this conformation the $\mathrm{C} 2=\mathrm{O} 1$ and $\mathrm{H}-\mathrm{N} 1$ groups form a pseudo 6-membered ring, favoring an $\mathrm{H}$-bond intramolecular interaction. For compound II, the minimum occurs at a dihedral angle ca. $60^{\circ}$, with mutual synclinal orientation of the $\mathrm{C} 1-\mathrm{N} 1$ and $\mathrm{C} 6-\mathrm{N} 2$ bonds (see Figs. 4 and 5 for atoms numbering).

The structures with $\delta(\mathrm{CN}-\mathrm{CN})=180^{\circ}$ correspond in both cases to local maxima in the potential energy curve, the energy barriers being ca. 15 and $11 \mathrm{kcal} / \mathrm{mol}$, higher for compound $\mathbf{I}$. Two equivalent local minima are observed at $\delta(\mathrm{CN}-\mathrm{CN})$ values of ca. 150 and $210^{\circ}$. These conformers are located higher in energy and correspond to structures with a nearly antiperiplanar orientation between the $\mathrm{C}-\mathrm{N}$ and $\mathrm{C}-\mathrm{N}$ bonds.

It is recognized that remote donor-acceptor orbital interactions can play a decisive role on the peptide backbone conformation [63]. In particular, it has been proposed that $\mathrm{C}=\mathrm{O} \cdots \mathrm{H}-\mathrm{N}$ hydrogen bonds [64] can

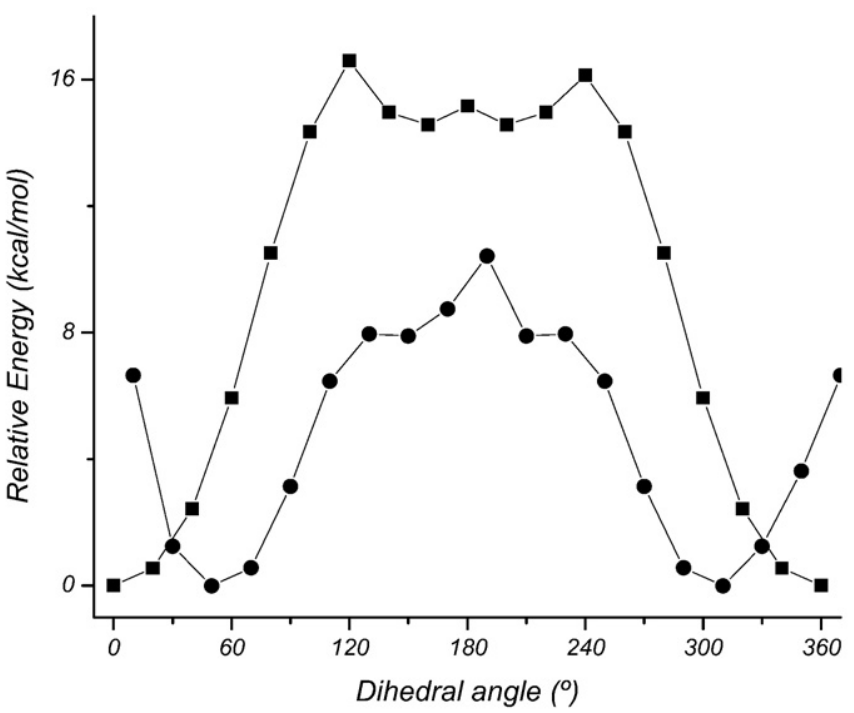

Fig. 3. Calculated [B3LYP/6-31 $+\mathrm{G}(\mathrm{d}, \mathrm{p})]$ potential function for internal rotation around the

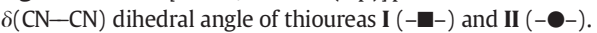




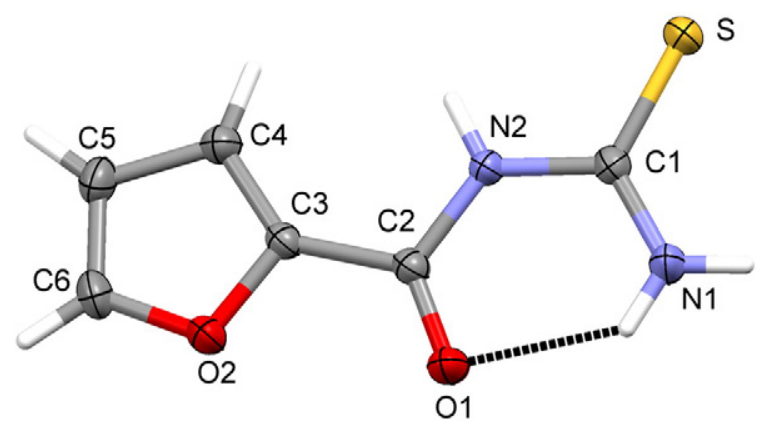

Fig. 4. The molecule structure of the compound I in the crystal. Ellipsoids represent 50\% probability levels and dashed line indicates intramolecular hydrogen bond.

be analyzed on the basis of the hyperconjugative interaction involving the partial transfer of a lone pair of electrons of the oxygen atom to the $\mathrm{N}-\mathrm{H}$ antibonding orbital [65]. For benzenesulfonylamin acetamide, $\mathrm{lpO} \rightarrow \sigma^{*}(\mathrm{~N}-\mathrm{H})$ interaction values of ca. $9.5 \mathrm{kcal} / \mathrm{mol}$ were computed by using DFT methods [66].

We applied the Natural Bond Orbital population analysis for determining electron donations in the studied compounds. For the compound I, the second-order perturbation analysis of the Fock matrix [B3LYP/6-311++G(d,p) level of approximation] indicates a lpO1 $\rightarrow \sigma^{*}(\mathrm{~N} 1-\mathrm{H})$ remote interaction, amounting to $8.1 \mathrm{kcal} / \mathrm{mol}$ for the $S$ form. The hyperconjugative interaction increases the electronic population of the $\sigma^{*}(\mathrm{~N} 1-\mathrm{H})$ orbital $(0.031 \mathbf{e})$, as compared with that of the second $\mathrm{N}-\mathrm{H}$ group, i.e. $\sigma^{*}(\mathrm{~N} 2-\mathrm{H})$, with 0.010 e. For compound II, without the possibility of forming intramolecular hydrogen bond, the $\sigma^{*}(\mathrm{~N} 1-\mathrm{H})$, shows an electronic population of $0.016 \mathbf{e}$.

The NBO analysis for the most stable conformers for compounds I and II, respectively, indicates the presence of pure p-type $\left[\mathrm{lp}_{\mathrm{p}}(\mathrm{N})\right]$ lone pair orbitals on both amide and thioamide nitrogen atoms. These orbitals display low electron occupancies (1.675 and 1.650 e and 1.703 and 1.597 e for the $\operatorname{lp}_{\mathrm{p}}(\mathrm{N} 1)$ and $\operatorname{lp}_{\mathrm{p}}(\mathrm{N} 2)$ of $\mathbf{I}$ and II, respectively) indicating their electron-donating capacity. The donor $\rightarrow$ acceptor interactions reveal that the lone pair orbital contributes to a strong resonance interactions with the carbonyl bond of the 2-furoyl group $\operatorname{lp}_{\mathrm{p}}(\mathrm{N} 2) \rightarrow \pi^{*}(\mathrm{C} 2=01)$, leading to the "amide resonance". The computed $\mathrm{E}^{(2)}$ interaction values are 57.0 and $41.0 \mathrm{kcal} / \mathrm{mol}$ for I and II, respectively, in good agreement with reported values for other 1-acyl thioureas [67].

The resonant forms also can involve the thioamide group and can be evaluated within the donor $\rightarrow$ acceptor approach, being the acceptor the $\pi^{*}(C=S)$ and $\sigma^{*}(C=S)$ antibonding orbitals. For compound $\mathbf{I}$, the $\operatorname{lp}_{\mathrm{p}}(\mathrm{N}) \rightarrow \pi^{*}(\mathrm{C} 1=\mathrm{S})$ interactions are computed to be 81.8 and $57.0 \mathrm{kcal} / \mathrm{mol}$ for the $\mathrm{N} 1$ and $\mathrm{N} 2$ nitrogen atoms, respectively. Lower values are obtained for II, amounting 75.3 and $41.0 \mathrm{kcal} / \mathrm{mol}$, respectively, probably because the non-planar structure disfavors these interactions.

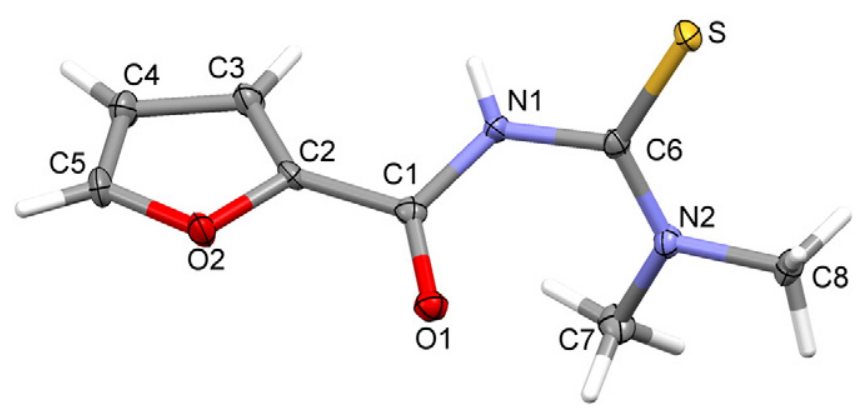

Fig. 5. Molecular structure of compound II. Displacement ellipsoids are drawn at the $50 \%$ probability level.

\subsubsection{X-ray Molecular Structure}

The molecular structure of crystalline 2-furoyl thiourea (I) is shown in Fig. 4. The compound I presents a nearly planar conformation, as a result, a pseudo six membered $(\mathrm{O} 1-\mathrm{C} 2-\mathrm{N} 2-\mathrm{C} 1-\mathrm{N} 1-\mathrm{H} 1 \mathrm{a})$ ring is formed, stabilizing an " $\mathrm{S}$ "-shaped conformation type. As a result the $\mathrm{C}=\mathrm{S}$ and $\mathrm{C}=\mathrm{O}$ groups are related to a maximum value of the $\mathrm{O}-\mathrm{S}$ distance [68], two donor sites rich in electron density and the trans geometry of the thiourea unit is stabilized by intramolecular $\mathrm{N} 1-\mathrm{H} 1 \mathrm{a} \cdots \mathrm{O} 1$ hydrogen bond, with $\mathrm{N} 1 \cdots \mathrm{O} 1$ distance of $2.676(2) \AA$ and $\mathrm{N} 1-\mathrm{H} \cdots \mathrm{O} 1$ bond angle of $132^{\circ}$. The $\mathrm{C} 1=\mathrm{S} 1$ and $\mathrm{O} 1-\mathrm{C} 1$ bonds show a typical double bond character with bond lengths of 1.672(2) Å and 1.223(2) A, respectively.

The Fig. 5 shows the molecular structure of the compound II. It is non planar forming a distorted -"S"-shaped conformation type, this conformation where the carbonyl and thiourea groups are non-planar with mutual anticlinal $\left(\mathrm{O}=\mathrm{C} / \mathrm{C}=\mathrm{S}=112.8^{\circ}\right)$ orientation of the $\mathrm{C}=\mathrm{S}$ and $\mathrm{C}=\mathrm{O}$ double bonds (see Fig. S5 in the Supporting information) [68]. The $\mathrm{C} 1=\mathrm{S} 1$ and $\mathrm{O} 1=\mathrm{C} 1$ bonds show a typical double bond character with bond lengths of 1.687(2) $\AA$ and 1.221(2) Å, respectively.

The amidic $(\mathrm{O}) \mathrm{C}-\mathrm{N} 2-\mathrm{H}$ and thioamide $\mathrm{N} 2 \mathrm{H}-\mathrm{C}(\mathrm{S})$ and $(\mathrm{S}) \mathrm{C}-\mathrm{N} 1$ bonds for I and $(\mathrm{O}) \mathrm{C}-\mathrm{N} 1-\mathrm{H}$ and thioamide $\mathrm{N} 1 \mathrm{H}-\mathrm{C}(\mathrm{S})$ and (S) C - N2 for II are both shorter than a $\mathrm{C}-\mathrm{N}$ single bond, typically ca. 1.472(5) A. This fact indicates that these bonds have a pronounced double bond character. It is deduced that these thiourea derivatives make up a multi-electron conjugated $\pi$ bond, in agreement with the NBO results discussed above. Other selected geometric parameters (Table 2) are between the ranges obtained for similar compounds [69].

\subsection{Crystal Packing and Topology Analysis of the Electron Densities}

Since many of the more relevant intra and intermolecular interactions involve hydrogen atoms, their positions in the crystal were optimized at the B3LYP/6-31G(d,p) level, keeping fixed at their crystallographic values the heavy atom positions and cell parameters. The electron density topology was analyzed and the values of the electron density and positive principal curvature of the Laplacian at the corresponding $(3,-1)$ critical point were used as indicators of the interaction strength. Topological parameters of the predominant intermolecular interactions present in the crystal structures of $\mathbf{I}$ and $\mathbf{I I}$ are reported in Tables 3 and 4, respectively.

In compound $\mathbf{I}$, the basic crystal substructures are the centrosymmetric molecular pairs involving, each, a pair of $\mathrm{N}-\mathrm{H} \cdots \mathrm{S}=\mathrm{C}$ interactions with one of the hydrogen atom in the amino group as donor ( $\mathrm{I}$ in Table 4), these being the most relevant from a topological view point. This pair can be classified as an $R_{2}^{2}(8)$ motif forming a pseudo eightmembered ring, as shown in Fig. S6 (Supporting information). In the structure of I the H1B $\cdots$ S is separated by $2.622 \AA$.

The crystal structure of $\mathbf{I}$, however, can be better described in terms of the infinite chains expanding in $\boldsymbol{c}$ axis direction (see Fig. 6a and Table 3), along which molecules are linked each other mainly through four interactions. The two strongest interactions link the carbonyl

Table 2

Selected bond distances ( $\AA$ ) for compounds I and II.

\begin{tabular}{llll}
\hline Compound I & & & \\
$\mathrm{S}-\mathrm{C} 1$ & $1.672(2)$ & $\mathrm{O} 1-\mathrm{C} 2$ & $1.223(2)$ \\
$\mathrm{O} 2-\mathrm{C} 3$ & $1.371(2)$ & $\mathrm{O}-\mathrm{C} 6$ & $1.352(2)$ \\
$\mathrm{N} 1-\mathrm{C} 1$ & $1.310(2)$ & $\mathrm{N} 2-\mathrm{C} 1$ & $1.390(2)$ \\
$\mathrm{N} 2-\mathrm{C} 2$ & $1.386(2)$ & $\mathrm{C} 2-\mathrm{C} 3$ & $1.455(2)$ \\
Compound II & & & \\
$\mathrm{S}-\mathrm{C} 6$ & & $\mathrm{O} 1-\mathrm{C} 1$ & $1.221(2)$ \\
$\mathrm{O} 2-\mathrm{C} 2$ & $1.687(2)$ & $\mathrm{O}-\mathrm{C} 5$ & $1.365(2)$ \\
$\mathrm{N} 1-\mathrm{C} 1$ & $1.372(2)$ & $\mathrm{N} 1-\mathrm{C} 6$ & $1.404(2)$ \\
$\mathrm{N} 2-\mathrm{C} 6$ & $1.387(2)$ & $\mathrm{N} 2-\mathrm{C} 7$ & $1.467(2)$ \\
$\mathrm{N} 2-\mathrm{C} 8$ & $1.321(2)$ & $\mathrm{C} 1-\mathrm{C} 2$ & $1.464(2)$ \\
\hline
\end{tabular}


Table 3

Topological parameters (atomic units) of the close shell intermolecular $(3,-1)$ critical points (electron density $(\rho)$, Laplacian $\left(\nabla^{2} \rho\right)$ and positive curvature $\left(\lambda_{3}\right)$ ) and geometrical parameters $\left(\AA\right.$ and $\left.{ }^{\circ}\right)$ of the interactions used in the structure description of compound $\mathbf{I}^{\mathrm{a}}$

\begin{tabular}{lllllll}
\hline & & $\rho$ & $\nabla^{2} \rho$ & $\lambda_{3}$ & $\mathrm{~d}_{\mathrm{H} \cdots \mathrm{O} / \mathrm{S} / \mathrm{N}}$ & $\theta_{\mathrm{D}-\mathrm{H} \cdots \mathrm{O} / \mathrm{S} / \mathrm{N}}$ \\
\hline I & $\mathrm{S} \cdots \mathrm{H}_{2} \mathrm{~N}(\mathrm{i})$ & 0.0175 & 0.0400 & 0.0755 & 2.461 & 164.8 \\
II & $\mathrm{C}=\mathrm{O} \cdots \mathrm{H}-\mathrm{N}(\mathrm{ii})$ & 0.0130 & 0.0444 & 0.0725 & 2.185 & 168.6 \\
III & $\mathrm{C}=\mathrm{O} \cdots \mathrm{H}_{\mathrm{R}}(\mathrm{iii})$ & 0.0126 & 0.0380 & 0.0642 & 2.339 & 151.1 \\
$\mathrm{IV}$ & $\mathrm{NH}_{2} \cdots \mathrm{S}$ (iv) & 0.0100 & 0.0332 & 0.0490 & 2.744 & 125.6 \\
V & $\mathrm{O}_{\mathrm{R}} \cdots \mathrm{H}_{\mathrm{R}}(\mathrm{v})$ & 0.0087 & 0.0312 & 0.0478 & 2.472 & 140.2 \\
VI & $\mathrm{H}_{\mathrm{R}} \cdots \mathrm{S}$ (vi) & 0.0076 & 0.0268 & 0.0388 & 2.768 & 159.2 \\
\hline
\end{tabular}

a Atom or group belonging to the reference molecule on the left of the interaction symbol. Between parenthesis symmetry operation generating the neighbor molecule (i: $-1-\mathrm{x}, 1-\mathrm{y},-\mathrm{z}$; ii: $\mathrm{x}, 1 / 2-\mathrm{y}, 1 / 2+\mathrm{z}$; iii: $\mathrm{x}, 1 / 2-\mathrm{y}, 1 / 2+\mathrm{z}$; iv: $-1-\mathrm{x}, 1-\mathrm{y},-\mathrm{z} ; \mathrm{v}$ : $\mathrm{x}, 1 / 2-\mathrm{y}, 1 / 2+\mathrm{z}$; vi: $1-\mathrm{x}, 1 / 2-\mathrm{y}, 1 / 2+\mathrm{z})$.

Table 4

Topological parameters (atomic units) of the $(3,-1)$ critical points (electron density $(\rho)$, Laplacian $\left(\nabla^{2} \rho\right)$ and positive curvature $\left(\lambda_{3}\right)$ ) and geometrical parameters ( $\left(\AA\right.$ and $\left.{ }^{\circ}\right)$ of the intermolecular interactions used in the structure description of compound II. $^{\mathrm{a}}$

\begin{tabular}{lllllll}
\hline & & $\rho$ & $\nabla^{2} \rho$ & $\lambda_{3}$ & $\mathrm{~d}_{\mathrm{H} \cdots \mathrm{O} / \mathrm{S} / \mathrm{N}}$ & $\theta_{\mathrm{D}-\mathrm{H} \cdots \mathrm{O} / \mathrm{S} / \mathrm{N}}$ \\
\hline $\mathrm{I}$ & $\mathrm{N}-\mathrm{H} \cdots \mathrm{S}$ (i) & 0.0188 & 0.0427 & 0.0810 & 2.425 & 157.4 \\
II & $\mathrm{H}_{\mathrm{R}} \cdots \mathrm{O}=\mathrm{C}$ (ii) & 0.0116 & 0.0440 & 0.0671 & 2.300 & 136.8 \\
III & $\mathrm{CH}_{3} \cdots \mathrm{O}=\mathrm{C}$ (iii) & 0.0104 & 0.0326 & 0.0534 & 2.431 & 150.5 \\
$\mathrm{IV}$ & $\mathrm{CH}_{3} \cdots \mathrm{O}=\mathrm{C}$ (iv) & 0.0095 & 0.0304 & 0.0494 & 2.463 & 157.79 \\
$\mathrm{~V}$ & $\mathrm{H}_{\mathrm{R}} \cdots \mathrm{S}$ (v) & 0.0085 & 0.0242 & 0.0378 & 2.850 & 159.7
\end{tabular}

a Atom or group belonging to the reference molecule on the left of the interaction symbol. Between parenthesis symmetry operation generating the neighbor molecule (i: $2-\mathrm{x},-\mathrm{y},-\mathrm{z}$; ii: $2-\mathrm{x}, 1 / 2+\mathrm{y}, 1 / 2-\mathrm{z}$; iii: $1-\mathrm{x},-1 / 2+\mathrm{y}, 1 / 2-\mathrm{z}$; iv: $2-\mathrm{x},-1 / 2+\mathrm{y}, 1 / 2-\mathrm{z} ; \mathrm{v}: 1-\mathrm{x},-\mathrm{y},-\mathrm{z})$.

oxygen atom with the amide hydrogen atom and with a hydrogen atom of the furoyl ring (II and III in Fig. 6 and Table 3). The other two interactions link an amino hydrogen atom with a sulfur atom (IV) and a hydrogen atom of the furoyl group with the oxygen atom also from a furoyl ring $(\mathrm{V})$. Chains, in turn, are linked each other through the above mentioned $\mathrm{N}-\mathrm{H} \cdots \mathrm{S}$ interactions and the $\mathrm{H}_{\mathrm{R}} \cdots \mathrm{S}$ ones (VI). Alternation in the molecule orientation along a chain (see Fig. 6b) ensures the main three dimensional interaction network is thus completed.

In compound II, the basic substructures are the centrosymmetric molecular pairs involving, each, a pair of $\mathrm{N}-\mathrm{H} \cdots \mathrm{S}$ interactions (I in Table 4 and Fig. 7). Linking of such pairs through $\mathrm{C}-\mathrm{H} \cdots \mathrm{O}$ interactions (III) involving methyl groups and acting in almost perpendicular directions (see Fig. 7 a), give rise to molecular layers parallel to $[1,0,2]$. The main three dimensional interaction network is completed by three interactions that link layers with each other (see Table 4 and Fig. 7b). Two of them involve carbonyl hydrogen atoms, a ring hydrogen atom (II) and a methyl hydrogen atom (IV) of the reference molecule being the donors. The remaining one is a $\mathrm{H} \cdots \mathrm{S}$ interaction $(\mathrm{V})$.

\subsection{Hirshfeld Surface Analysis}

Intermolecular contacts were also explored using both Hirshfeld surfaces and fingerprint plots. In recent years, many research groups have used Hirshfeld surfaces [70,71] and their two-dimensional fingerprints as an important tool to visualize and analyze structural properties in relation to packing patterns [72], including those observed in thiourea compounds [73,74]. The intermolecular interactions of I and II were analyzed using the Hirshfeld surface and the corresponding twodimensional fingerprint plots [75] are shown in the Fig. 8.

The $3 \mathrm{D} \mathrm{d}_{\text {norm }}$ Hirshfeld surfaces for $\mathbf{I}$ and $\mathbf{I I}$ are represented in the Fig. $8 \mathrm{~A}$, in which the value of $\mathrm{d}_{\text {norm }}$ can be negative, positive or zero, when intermolecular contacts are shorter, longer or equal to van der Waals ( $v d W$ ) radii, respectively. The $\mathrm{d}_{\text {norm }}$ values were mapped onto the Hirshfeld surface using a color gradient from blue to red indicates that region able to perform intermolecular interactions. Red regions represent closer contacts and a negative $d_{\text {norm }}$ value, while blue regions represent longer contacts and a positive $d_{\text {norm }}$ value. In the surface, white regions represent the distance of contacts equal to exactly the vdW separation with a $d_{\text {norm }}$ value of zero. As can be seen in the Hirshfeld surfaces of the compounds I and II the most intense red
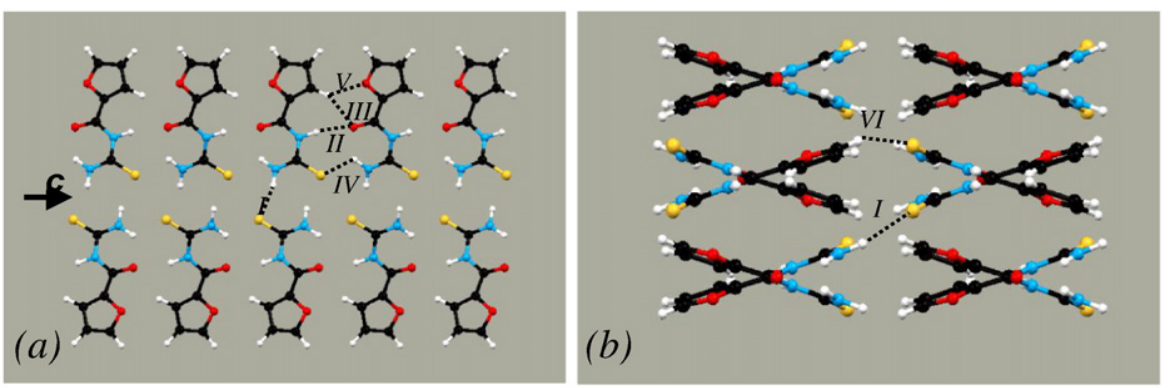

Fig. 6. (a) Two chains view along $\boldsymbol{b}$ axis direction, in the compound $\mathbf{I}$. (b) Six chains view along $\boldsymbol{c}$ axis direction.
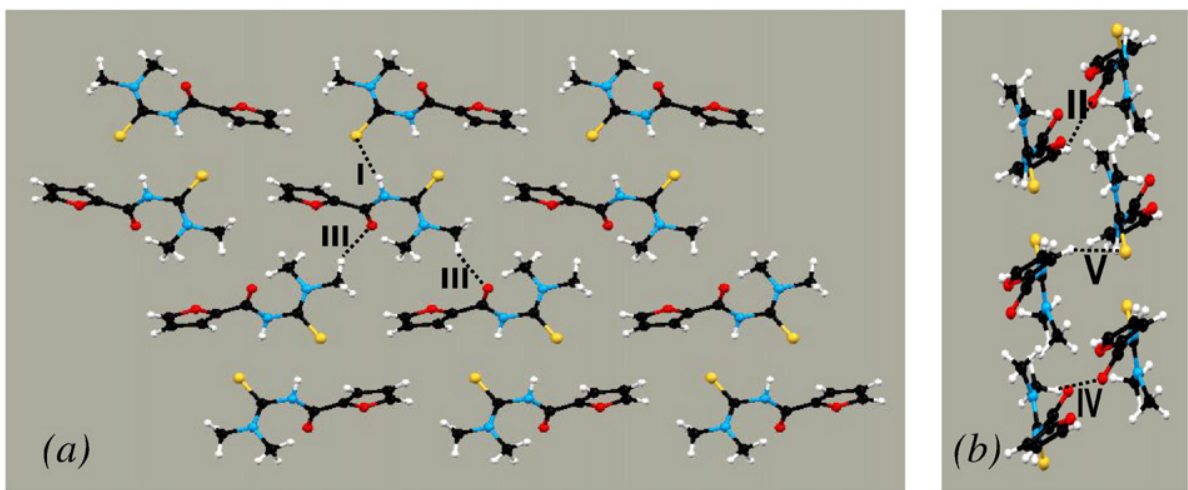

Fig. 7. (a) Layer view along a normal to $[1,0,2]$. (b) Two layers view along $\boldsymbol{b}$ axis direction in the compound II. 


\section{(A) Hirshfeld surfaces}

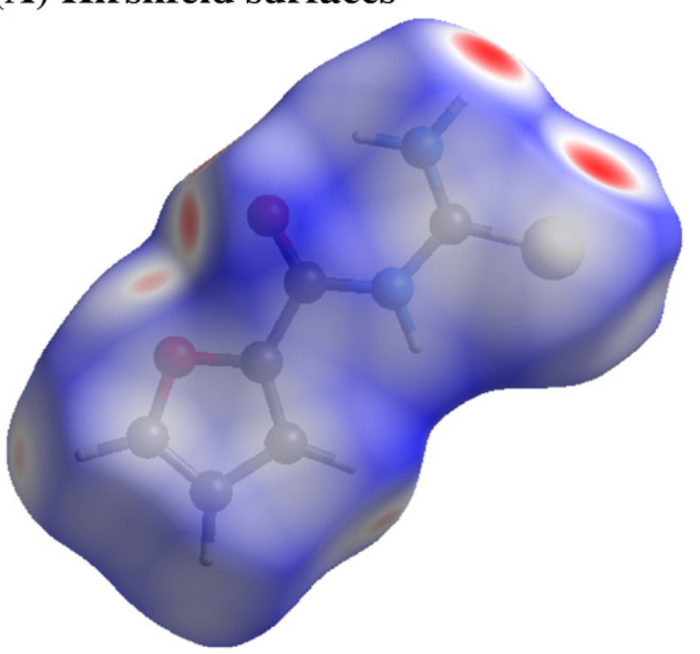

(B) Full fingerprint plot

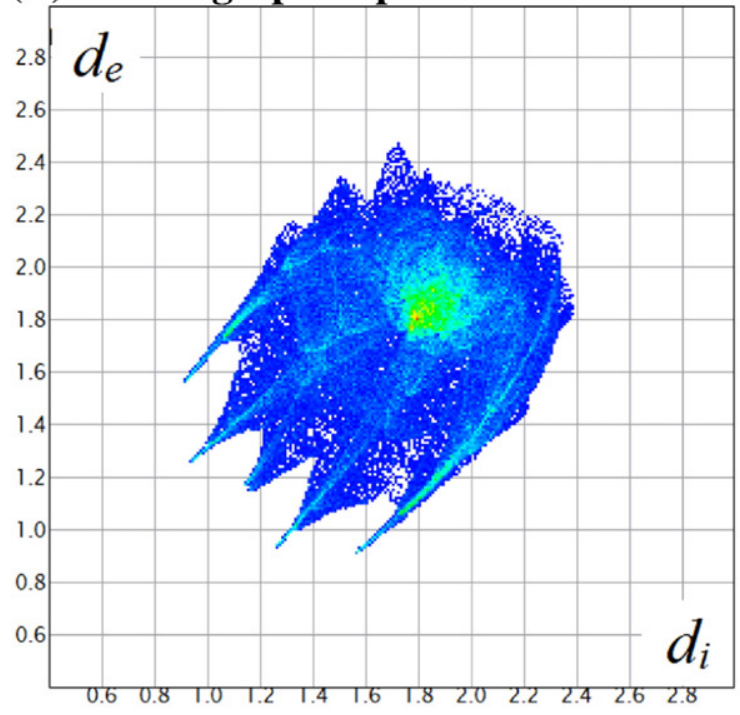

(C) $\mathrm{S} \cdots \mathbf{H}$

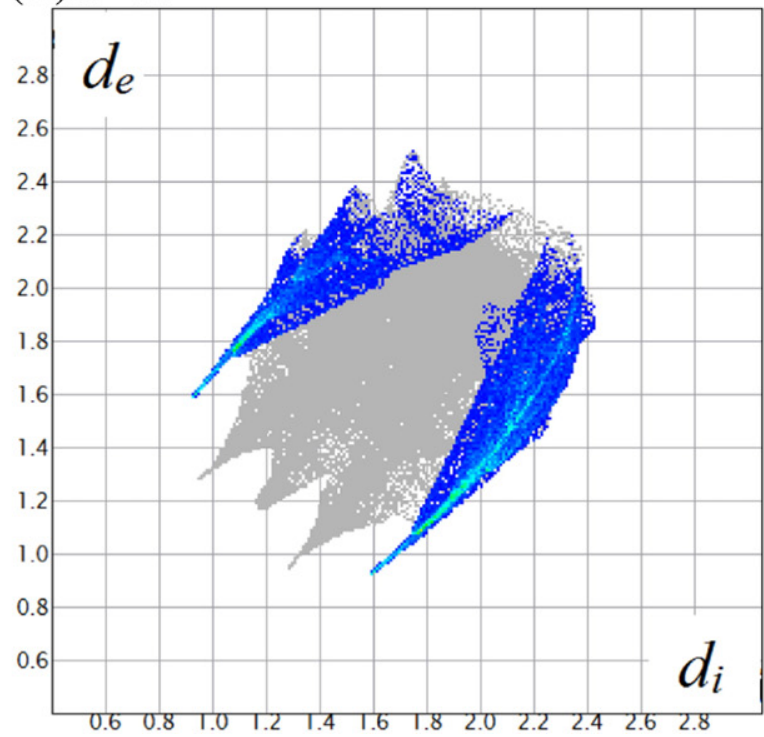

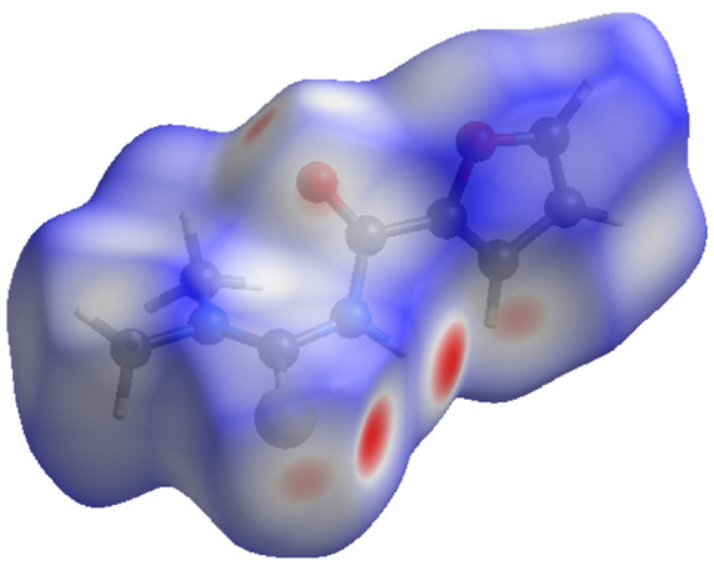
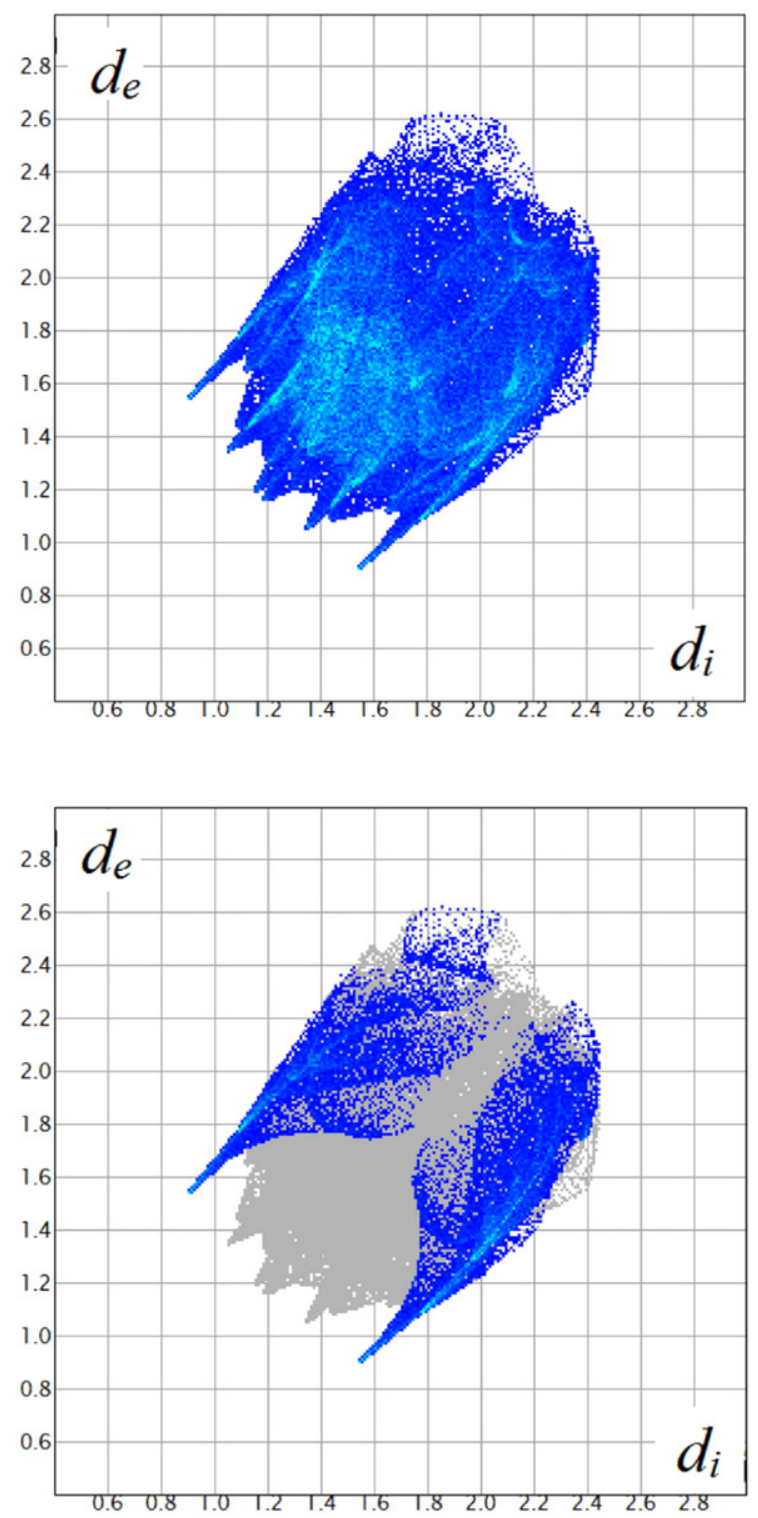

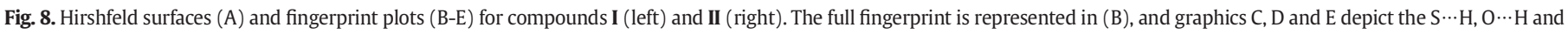
$\mathrm{H} \cdots \mathrm{H}$ intermolecular contacts, respectively. 


\section{(D) $\mathbf{O} \cdots \mathbf{H}$}

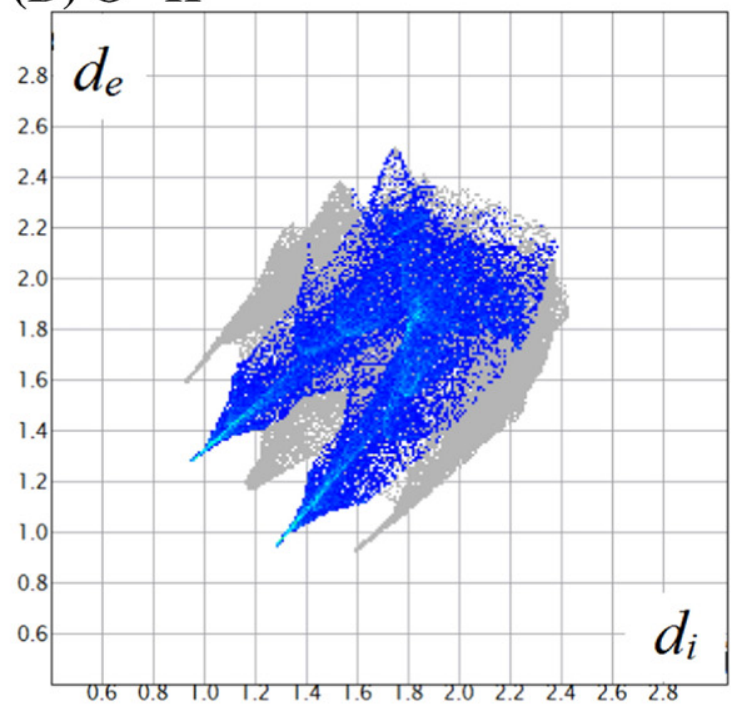

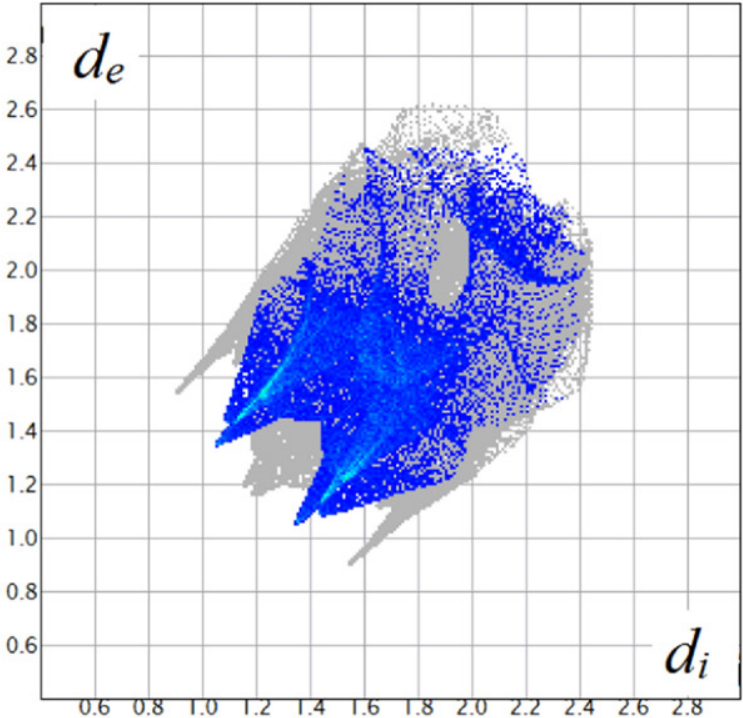

\section{(E) $\mathbf{H} \cdots \mathbf{H}$}
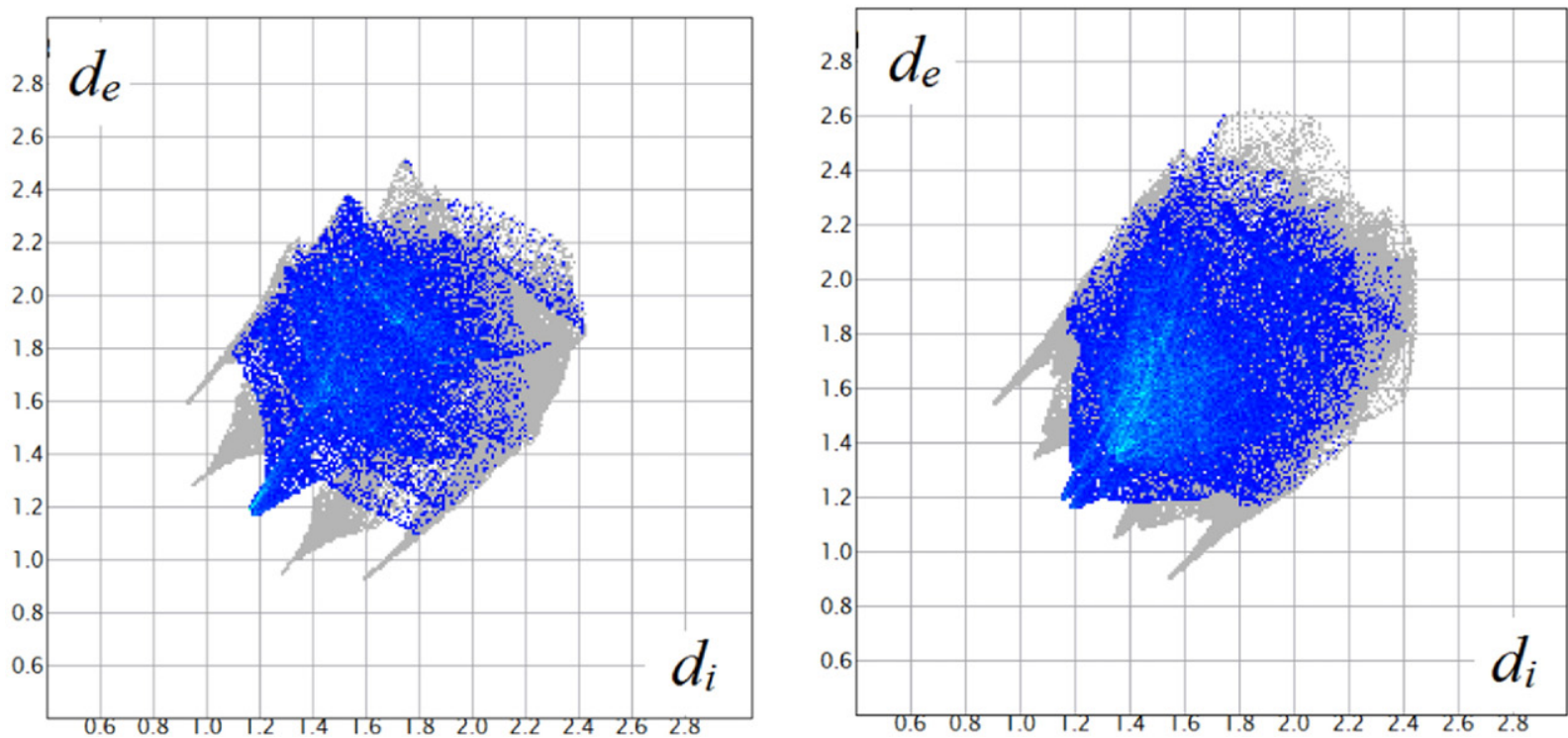

Fig. 8 (continued).

regions occur near to $\mathrm{C}=\mathrm{S}$ and $\mathrm{N}-\mathrm{H}$ groups, due to bifurcate $\mathrm{N}-\mathrm{H} \cdots \mathrm{S}$ hydrogen bonds present in both structures (see Fig. S6 in the Supporting information). The compound I also exhibits red regions close to both oxygen atoms of carbonyl and furoyl groups, as a result of $\mathrm{N}-\mathrm{H} \cdots \mathrm{O}$ and $\mathrm{C}-\mathrm{H} \cdots \mathrm{O}$ hydrogen bonds, respectively, such as illustrated in the Fig. $6 a$ and discussed in the crystal packing analysis. Differently, when we look at to Hirshfeld surface of the compound II, it is observed that the oxygen atom of the furoyl group is not involved in any close intermolecular contact, resulting in a white-to-blue gradient color in the Hirshfeld surface. Meanwhile the less intense red color gradient in II is observed on oxygen atom of the carbonyl, because this group is involved in a non-classical $\mathrm{C}-\mathrm{H} \cdots \mathrm{O}$ hydrogen bond, such as represented in Table 4 and Fig. 7.

The fingerprint plots of the two molecules show the presence of $\mathrm{S} \cdots \mathrm{H}, \mathrm{O} \cdots \mathrm{H}$ and $\mathrm{H} \cdots \mathrm{H}$ intermolecular contacts (Fig. 8B). The relative contribution of the main intermolecular contacts present in each compound is listed in the Table S3 (Supporting information). The biggest contribution includes hydrophobic intermolecular contacts $(\mathrm{H} \cdots \mathrm{H}$,
$\mathrm{C} \cdots \mathrm{H}$ and $\mathrm{C} \cdots \mathrm{C})$. In addition, the hydrogen bonding $(\mathrm{S} \cdots \mathrm{H}$ and $\mathrm{O} \cdots \mathrm{H})$ form well defined contacts as represented in the Fig. 8C-D, acting as driving forces to stabilize the crystal packing. Therefore, the hydrophobic intermolecular contacts together with the $\mathrm{N}-\mathrm{H} \cdots \mathrm{S}$ hydrogen bonds provide forces for self-assembly in the compounds.

\section{Conclusions}

Two 2-furoyl thiourea derivatives (I and II) were prepared and their structural and spectroscopic properties have been determined. Our results clearly show that the conformation of the central acyl-thiourea $[-\mathrm{C}(\mathrm{O}) \mathrm{NHC}(\mathrm{S}) \mathrm{N}<]$ moiety depends on the substitution at the nitrogen atom. Thus, the simplest 2-furoyl thiourea (I) adopts a planar structure with the $\mathrm{C}=\mathrm{O}$ and $\mathrm{C}=\mathrm{S}$ double bonds mutually oriented in a pseudoantiperiplanar arrange, favoring a strong $\mathrm{C}=\mathrm{O} \cdots \mathrm{H}-\mathrm{N}$ intramolecular hydrogen bond. The same conformation was very recently found in the crystal of the mono-substituted 3-phenyl thiourea [76]. However, di-methylation of the $-\mathrm{NH}_{2}$ group leads to a different conformation 
of the thiourea group: planarity is absent in compound II and anticlinal orientation of the $\mathrm{C}=\mathrm{S}$ and $\mathrm{C}=\mathrm{O}$ double bonds is observed. Inversion dimers with an $\mathrm{R}_{2}^{2}(8)$ ring motif are observed for I and II, a supramolecular synthon that is assisted by strong $\mathrm{N}-\mathrm{H} \cdots \mathrm{S}=$ C hydrogen bonds, as characterized by topological grounds and Hirshfeld surface analysis.

\section{Acknowledgments}

DBS, ACF and MFE are member of the Carrera del Investigador of CONICET (República Argentina). The Argentinean authors thank to the Consejo Nacional de Investigaciones Científicas y Técnicas (CONICET), the ANPCYT (PICT-2013-2130) and to the Facultad de Ciencias Exactas, Universidad Nacional de La Plata for financial support. This work was supported by CAPES (Project Oficio/CSS/CGCI/23038009487/2011-25/ DRI/CAPES, AUX CAPES-MES-Cuba, 339/2011), of Brazil. MFE also thanks Prof. Romano (CEQUINOR) for helping measuring the Raman spectra.

\section{Appendix A. Supplementary data}

Cartesian coordinates of optimized structures [B3LYP/6$311++\mathrm{G}(\mathrm{d}, \mathrm{p})]$ for compounds I and II are given in Tables S1 and S2, respectively. In Table $\mathrm{S} 3$ the relative contribution to the Hirshfeld surfaces of the important intermolecular contacts present in each compound, I and $\mathbf{I I}$ are given. ${ }^{1} \mathrm{H}$ and ${ }^{13} \mathrm{C}$ NMR spectra are given in Figs. S1-S4. Conformations of molecules of compound I are shown in Fig. S5 and centrosymmetric dimer the studied compounds are shown in Fig. S6. Supplementary data associated with this article can be found in the online version, at [10.1016/j.saa.2016.12.038].

\section{References}

[1] K.R. Koch, New chemistry with old ligands: $N$-alkyl- and $N, N$-dialkyl- $N^{\prime}-$ acyl(aroyl)thioureas in co-ordination, analytical and process chemistry of the platinum group metals, Coord. Chem. Rev. 216-217 (2001) 473-488.

[2] A.A. Aly, E.K. Ahmed, K.M. El-Mokadem, M.E.-A.F. Hegazy, Update survey on aroyl substituted thioureas and their applications, J. Sulfur Chem. 28 (2007) 73-93.

[3] A. Saeed, U. Flörke, M.F. Erben, A review on the chemistry, coordination, structure and biological properties of 1-(acyl/aroyl)-3-(substituted) thioureas, J. Sulfur Chem. 35 (2014) 318-355.

[4] A. Saeed, R. Qamar, T.A. Fattah, U. Flörke, M.F. Erben, Recent developments in chemistry, coordination, structure and biological aspects of 1-(acyl/aroyl)-3-(substituted) thioureas, Res. Chem. Intermed. (2016) 1-41 In press 10.1007/s11164-016-2811-5.

[5] P.V. Tran, S.A. Lachke, R.W. Stottmann, Toward a systems-level understanding of the Hedgehog signaling pathway: defining the complex, robust, and fragile, WIREs Syst. Biol. Med. 5 (2013) 83-100.

[6] A. Solinas, H. Faure, H. Roudaut, E. Traiffort, A. Schoenfelder, A. Mann, F. Manetti, M. Taddei, M. Ruat, Acylthiourea, acylurea, and acylguanidine derivatives with potent hedgehog inhibiting activity, J. Med. Chem. 55 (2012) 1559-1571.

[7] F. Manetti, H. Faure, H. Roudaut, T. Gorojankina, E. Traiffort, A. Schoenfelder, A Mann, A. Solinas, M. Taddei, M. Ruat, Virtual screening-based discovery and mechanistic characterization of the acylthiourea MRT-10 family as smoothened antagonists, Mol. Pharmacol. 78 (2010) 658-665.

[8] Y. Zhang, J. Qin, Q. Lin, T. Wei, Convenient synthesis and anion recognition properties of $N$-flurobenzoyl- $N^{\prime}$-phenylthioureas in water-containing media, J. Fluor. Chem. 127 (2006) 1222-1227.

[9] M. Boiocchi, L. Del Boca, D.E. Gomez, L. Fabbrizzi, M. Licchelli, E. Monzani, Nature of urea-fluoride interaction: incipient and definitive proton transfer, J. Am. Chem. Soc. 126 (2004) 16507-16514.

[10] M. Bonizzoni, L. Fabbrizzi, A. Taglietti, F. Tiengo, (Benzylideneamino)thioureas chromogenic interactions with anions and $\mathrm{N}-\mathrm{H}$ deprotonation, Eur. J. Org. Chem. 2006 (2006) 3567-3574.

[11] Z. Weiqun, L. Baolong, Z. Liming, D. Jiangang, Z. Yong, L. Lude, Y. Xujie, Structural and spectral studies on $N$-(4-chloro)benzoyl- $N^{\prime}$-(4-tolyl)thiourea, J. Mol. Struct. 690 (2004) 145-150.

[12] T. Yesilkaynak, G. Binzet, F.M. Emen, U. Flörke, N. Külcü, H. Arslan, Theoretical and experimental studies on $\mathrm{N}$-(6-methylpyridin-2-yl-carbamothioyl)biphenyl-4carboxamide, Eur. J. Chem. 1 (2010) 1-5.

[13] A.M. Plutín, H. Márquez, E. Ochoa, M. Morales, M. Sosa, L. Morán, Y. Rodríguez, M. Suárez, N. Martín, C. Seoane, Alkylation of benzoyl and furoylthioureas as polydentate systems, Tetrahedron 56 (2000) 1533-1539.

[14] V. Vrdoljaka, M. Cindrića, D. Milića, D. Matković-Čalogovića, P. Novakb, B. Kamenar, Synthesis of five new molybdenum(VI) thiosemicarbazonato complexes. Crystal structures of salicylaldehyde and 3-methoxy-salicylaldehyde 4methylthiosemicarbazones and their molybdenum(VI) complexes, Polyhedron 24 (2005) 1717-1726.
[15] A. Okuniewski, J. Chojnacki, B. Becker, 3,3'-Dibenzoyl-1,1'-dibenzyl-1,1'-(ethane1,2-diyl)dithiourea, Acta Crystallogr. E68 (2012) o619-0620.

[16] A. Saeed, U. Flörke, 1-(3-Methoxyphenyl)-3-(4-methylbenzoyl)thiourea, Acta Crystallogr. E63 (2007) 03695.

[17] H. Arslan, D.S. Mansuroglu, D. VanDerveer, G. Binzet, The molecular structure and vibrational spectra of $N$-(2,2-diphenylacetyl)- $N^{\prime}$-(naphthalen-1yl)-thiourea by Hartree-Fock and density functional methods, Spectrochim. Acta 72A (2009) $561-571$.

[18] A. Saeed, M.F. Erben, U. Flörke, Effect of fluorine substitution on the crystal structures and vibrational properties of phenylthiourea isomers, J. Mol. Struct. 982 (2010) 91-99.

[19] K. Gholivand, S. Farshadian, M.F. Erben, C.O. Della Védova, Synthesis and characterization of the first phosphonic diamide containing thiazolyl groups: structural properties and tautomeric equilibrium, J. Mol. Struct. 978 (2010) 67-73.

[20] J. Duque, O. Estevez-Hernandez, E. Reguera, R.S. Correa, P. Gutierrez Maria, 1-(2Furoyl)-3-(1-naphthyl)thiourea, Acta Crystallogr. E64 (2008) 01068.

[21] O. Estévez-Hernández, E. Otazo-Sánchez, J.L. Hidalgo-Hidalgo de Cisneros, I. Naranjo-Rodríguez, E. Reguera, A Raman and infrared study of 1-furoyl-3monosubstituted and 3,3-disubstituted thioureas, Spectrochim. Acta A62 (2005) 964-971.

[22] R.S. Correa, O. Estevez-Hernandez, J. Ellena, J. Duque, 1-(2-Furoyl)-3-(otolyl)thiourea, Acta Crystallogr. Sect. E: Struct. Rep. Online 64 (2008) 01414

[23] O. Estevez-Hernandez, J. Duque, H. Pérez, S. Santos Jr., Y. Mascarenhas, N-(2-furoyl)$N^{\prime}$-(2-pyridyl)thiourea, Acta Crystallogr. Sect. E: Struct. Rep. Online 65 (2009) o929-0930.

[24] M.E. Defonsi Lestard, D.M. Gil, O. Estevez-Hernandez, M.F. Erben, J. Duque, Structural, vibrational and electronic characterization of 1-benzyl-3-furoyl-1-phenylthiourea: an experimental and theoretical study, New J. Chem. 39 (2015) 7459-7471.

[25] E. Otazo-Sanchez, L. Pérez-Marin, O. Estevez-Hernandez, S. Rojas-Lima, J. AlonsoChamarro, Aroylthioureas: new organic ionophores for heavy-metal ion selective electrodes, J. Chem. Soc. Perkin Trans. 2 (2001) 2211-2218.

[26] O. Estévez-Hernández, E. Otazo-Sánchez, J.L.H.-H.d. Cisneros, I. Naranjo-Rodríguez, E. Reguera, Novel $\mathrm{CdCl} 2$ and $\mathrm{HgCl} 2$ complexes with 3-monosubstituted and 3,3-disubstituted 1-furoylthioureas: IR and Raman spectra, Spectrochim. Acta A64 (2006) 961-971.

[27] H. Pérez, R.S. Corrêa, A.M. Plutín, O. Calderon, J. Duque, cis-Bis[ $N$-(2-furoyl)- $N^{\prime}, N^{\prime}-$ diphenylthioureato-k20,S]nickel(II), Acta Crystallogr. Sect. E: Struct. Rep. Online 65 (2009) m242.

[28] H. Pérez, B. O'Reilly, A.M. Plutín, R. Martínez, R. Durán, I.G. Collado, Y.P. Mascarenhas, Synthesis, characterization, and crystal structure of $\mathrm{Ni}(\mathrm{II})$ and $\mathrm{Cu}(\mathrm{II})$ complexes with $N$-furoyl- $N^{\prime}$-diethylthiourea: antifungal activity, J. Coord. Chem. 64 (2011) 2890-2898.

[29] L.M. Cubillana-Aguilera, J.M. Palacios-Santander, O.L. Estévez-Hernández, I. NaranjoRodríguez, J.L. Hidalgo-Hidalgo de Cisneros, 1-Furoylthiourea-sonogel-carbon electrodes: structural and electrochemical characterization, Talanta 82 (2010) 129-136.

[30] D. Wilson, M.Á. Arada, S. Alegret, M. del Valle, Lead(II) ion selective electrodes with PVC membranes based on two bis-thioureas as ionophores: 1,3-bis $\left(N^{\prime}\right.$ benzoylthioureido)benzene and 1,3-bis( $N^{\prime}$-furoylthioureido)benzene, J. Hazard. Mater. 181 (2010) 140-146.

[31] M. Mureseanu, A. Reiss, N. Cioatera, I. Trandafir, V. Hulea, Mesoporous silica functionalized with 1-furoyl thiourea urea for $\mathrm{Hg}$ (II) adsorption from aqueous media, J. Hazard. Mater. 182 (2010) 197-203.

[32] P. Hohenberg, W. Kohn, Inhomogeneous electron gas, Phys. Rev. 136 (1964) B864-B871.

[33] W. Kohn, L. Sham, Self-consistent equations including exchange and correlation effects, Phys. Rev. 140 (1965) A1133-A1138.

[34] M.J. Frisch, G.W. Trucks, H.B. Schlegel, G.E. Scuseria, M.A. Robb, J.R. Cheeseman, J.A. Montgomery Jr., T. Vreven, K.N. Kudin, J.C. Burant, J.M. Millam, S.S. Iyengar, J. Tomasi, V. Barone, B. Mennucci, M. Cossi, G. Scalmani, N. Rega, G.A. Petersson, H. Nakatsuji, M. Hada, M. Ehara, K. Toyota, R. Fukuda, J. Hasegawa, M. Ishida, T. Nakajima, Y. Honda, O. Kitao, H. Nakai, M. Klene, X. Li, J.E. Knox, H.P. Hratchian, J.B. Cross, C. Adamo, J. Jaramillo, R. Gomperts, R.E. Stratmann, O. Yazyev, A.J. Austin, R. Cammi, C. Pomelli, J.W. Ochterski, P.Y. Ayala, K. Morokuma, G.A. Voth, P. Salvador, J.J. Dannenberg, V.G. Zakrzewski, S. Dapprich, A.D. Daniels, M.C. Strain, O. Farkas, D.K. Malick, A.D. Rabuck, K. Raghavachari, J.B. Foresman, J.V. Ortiz, Q. Cui, A.G. Baboul, S. Clifford, J. Cioslowski, B.B. Stefanov, G. Liu, A. Liashenko, P. Piskorz, I. Komaromi, R.L. Martin, D.J. Fox, T. Keith, M.A. Al-Laham, C.Y. Peng, A. Nanayakkara, M. Challacombe, P.M.W. Gill, B. Johnson, W. Chen, M.W. Wong, C. Gonzalez, J.A. Pople, Gaussian 03, Gaussian, Inc., Pittsburgh PA, 2003.

[35] M.J. Frisch, J.A. Pople, J.S. Binkley, Self-consistent molecular orbital methods 25. Supplementary functions for Gaussian basis sets, J. Chem. Phys. 80 (1984) 3265-3269.

[36] A.E. Reed, L.A. Curtiss, F. Weinhold, Intermolecular interactions from a natural bond orbital, donor-acceptor viewpoint, Chem. Rev. 88 (1988) 899-926.

[37] R. Dovesi, V.R. Saunders, C. Roetti, R. Orlando, C.M. Zicovich-Wilson, F. Pascale, B. Civalleri, K. Doll, N.M. Harrison, I.J. Bush, P. D'Arco, M. Llunell, M. Causà, Y. Noël, CRYSTAL14 User's Manual, University of Torino, Torino, 2014.

[38] C. Gatti, V.R. Saunders, C. Roetti, Crystal field effects on the topological properties of the electron density in molecular crystals: the case of urea, J. Chem. Phys. 101 (1994) 10686-10696.

[39] C. Gatti, S. Casassa, TOPOND User's Manual, CNR-ISTM of Milano, Milano, 2014.

[40] Enraf-Nonius, Collect, Nonius BV, Delft, The Netherlands, 1997-2000.

[41] Z. Otwinowski, W. Minor, Processing of X-ray diffraction data collected in oscillation mode, in: J.C.W. Carter, R.M. Sweet (Eds.),Methods in Enzymology, Macromolecular Crystallography, Part A 1997, pp. 307-326.

[42] R.H. Blessing, An empirical correction for absorption anisotropy, Acta Crystallogr. A51 (1995) 33-38. 
[43] G. Sheldrick, A short history of SHELX, Acta Crystallogr. A64 (2008) 112-122.

[44] J.L. Farrugia, Ortep-3 for Windows, J. Appl. Crystallogr. 30 (1997) 565

[45] I.B. Douglass, F.B. Dains, Some derivatives of benzoyl and furoyl isothiocyanates and their use in synthesizing heterocyclic compounds, J. Am. Chem. Soc. 56 (1934) 719-721.

[46] P.P. Tadbuppa, E.R.T. Tiekink, (E)-O-ethyl N-(4-chlorophenyl)thiocarbamate, Acta Crystallogr. E63 (2007) 01779-01780.

[47] J. Dillen, M.G. Woldu, K.R. Koch, $N, N$-(heptane-2,6-diyl)- $N^{\prime}-(3,4,5$ methoxybenzoyl)thiourea, Acta Crystallogr. E62 (2006) 05225-05227.

[48] J. Goerdeler, R. Losch, Über Acylcarbodiimide, III. Darstellung und Reaktionen von (Thiocarbamoyl)carbodiimiden, Chem. Ber. 113 (1980) 79-89.

[49] C.G. Overberger, H.A. Friedman, Thioureas and isothiuronium salts. Polymeric derivatives, J. Polym. Sci., Part A: Gen. Pap. 3 (1965) 3625-3634.

[50] H. Arslan, U. Flörke, N. Külcü, Theoretical studies of molecular structure and vibrational spectra of O-ethyl benzoylthiocarbamate, Spectrochim. Acta 67A (2007) 936-943.

[51] S. Torrico-Vallejos, M.F. Erben, R. Boese, O.E. Piro, E.E. Castellano, C.O. Della Védova, Structural effects and hydrogen bonds on $N, N^{\prime}$-di(methoxycarbonylsulfenyl)urea, $\left[\mathrm{CH}_{3} \mathrm{OC}(\mathrm{O}) \mathrm{SNH}\right]_{2} \mathrm{CO}$, studied by experimental and theoretical methods, J. Mol. Struct. 918 (2009) 146-153.

[52] A. Saeed, M.F. Erben, M. Bolte, Structural and vibrational study on N-(biphenyl-2thiocarbamoyl)-4-phenylcarboxamide, J. Mol. Struct. 985 (2010) 57-62.

[53] A. Saeed, M.F. Erben, N. Abbas, U. Flörke, Synthesis, crystal X-ray diffraction struc ture, vibrational properties and quantum chemical calculations on 1-(4-(4fluorobenzamido)phenyl)-3-(4-fluorobenzoyl)thiourea, J. Mol. Struct. 984 (2010) 240-245.

[54] H. Arslan, N. Külcü, U. Flörke, et al., Spectrochim. Acta 64A (2006) 1065-1071.

[55] A. Saeed, U. Flörke, M.F. Erben, The role of substituents in the molecular and crystal structure of 1-(adamantane-1-carbonyl)-3-(mono)- and 3,3-(di) substituted thioureas, J. Mol. Struct. 1065-1066 (2014) 150-159.

[56] M. Dzurilla, P. Kutschy, J. Imrich, S. Brtoš, Hugershoff reaction of $N-1-$ or $N-2-$ naphthoyl- $N^{\prime}$-monosubstituted and $N^{\prime}, N^{\prime}$-disubstituted thiourea derivatives, Collect. Czechoslov. Chem. Commun. 59 (1994) 2663-2676.

[57] M.S.M. Yusof, R.H. Jusoh, W.M. Khairul, B.M. Yamin, Synthesis and characterisation a series of $N$-(3,4-dichlorophenyl)- $N^{\prime}$-(2,3 and 4-methylbenzoyl)thiourea derivatives, J. Mol. Struct. 975 (2010) 280-284.

[58] A. Saeed, M.F. Erben, U. Shaheen, U. Flörke, Synthesis, structural and vibrational properties of 1-(4-fluorobenzoyl)-3-(isomeric fluorophenyl)thioureas, J. Mol. Struct. 1000 (2011) 49-57.

[59] W. Yang, W. Zhou, Z. Zhang, Structural and spectroscopic study on N-2fluorobenzoyl- $N^{\prime}-4$-methoxyphenylthiourea, J. Mol. Struct. 828 (2007) 46-53.

[60] E. Otazo-Sánchez, P. Ortiz-del-Toro, O. Estévez-Hernández, L. Pérez-Marín, I. Goicoechea, A. Cerón Beltran, J.R. Villagómez-Ibarra, Aroylthioureas: new organic ionophores for heavy metal ion selective electrodes. A nuclear magnetic resonance study, Spectrochim. Acta 58A (2002) 2281-2290

[61] A. Macías, A. Rosado, E. Otazo, Pyrolysis of 1-furoyl-3-phenylthioureas in mass spectrometry, J. Anal. Appl. Pyrolysis 38 (1996) 55-60.
[62] A.E.-A.M. Gaber, O.S. Mohamed, Thermal fragmentation of some aryl thiourea derivatives, Phosphorus Sulfur Silicon 174 (2001) 193-199.

[63] A.J. Lopes Jesus, M.T.S. Rosado, I. Reva, R. Fausto, M.E.S. Eusébio, J.S. Redinha, Structure of isolated 1,4-butanediol: combination of MP2 calculations, NBO analysis, and matrix-isolation infrared spectroscopy, J. Phys. Chem. A 112 (2008) 4669-4678.

[64] G.R. Desiraju, Hydrogen bridges in crystal engineering: interactions without borders, Acc. Chem. Res. 35 (2002) 565-573.

[65] I.V. Alabugin, M. Manoharan, S. Peabody, F. Weinhold, Electronic basis of improper hydrogen bonding: a subtle balance of hyperconjugation and rehybridization, J. Am. Chem. Soc. 125 (2003) 5973-5987.

[66] L. Aguilar-Castro, M. Tlahuextl, L.H. Mendoza-Huizar, A.R. Tapia-Benavides, H. Tlahuext, Hydrogen bond studies in substituted $\mathrm{N}$-(2-hydroxyphenyl)-2-[(4methylbenzenesulfonyl)amino]acetamides, ARKIVOC (2008) 210-226.

[67] A. Saeed, A. Khurshid, M. Bolte, A.C. Fantoni, M.F. Erben, Intra- and intermolecular hydrogen bonding and conformation in 1-acyl thioureas: an experimental and theoretical approach on 1-(2-chlorobenzoyl)thiourea, Spectrochim. Acta 143A (2015) 59-66.

[68] C.K. Özer, H. Arslan, D. VanDerveer, N. Külcü, Synthesis and characterization of $N$ (arylcarbamothioyl)-cyclohexanecarboxamide derivatives: the crystal structure of $N$-(naphthalen-1-ylcarbamothioyl)cyclohexanecarboxamide, Molecules 14 (2009) 655-666.

[69] O. Estévez-Hernández J. Duque, E. Reguera, Structural features of 1-furoylthioureas 3-monosubstituted and 3,3-disubstituted: coordination to cadmium and analytical applications, J. Sulfur Chem. 32 (2011) 213-222.

[70] M.A. Spackman, D. Jayatilaka, Hirshfeld surface analysis, CrystEngComm 11 (2009) 19-32.

[71] J.J. McKinnon, D. Jayatilaka, M.A. Spackman, Towards quantitative analysis of intermolecular interactions with Hirshfeld surfaces, Chem. Commun. (2007) 3814-3816.

[72] H. Pérez, R.S. Correa, A.M. Plutin, B. O'Reilly, M.B. Andrade, Probing the relationships between molecular conformation and intermolecular contacts in $N, N$-dibenzyl- $N^{\prime}-$ (furan-2-carbonyl)thiourea, Acta Crystallogr. C 68 (2012) 019-022.

[73] A. Saeed, M. Bolte, M.F. Erben, H. Perez, Intermolecular interactions in crystalline 1(adamantane-1-carbonyl)-3-substituted thioureas with Hirshfeld surface analysis, CrystEngComm 17 (2015) 7551-7563.

[74] A. Saeed, S. Ashraf, U. Flörke, Z.Y. Delgado Espinoza, M.F. Erben, H. Pérez, Supramolecular self-assembly of a coumarine-based acylthiourea synthon directed by Ï€stacking interactions: crystal structure and Hirshfeld surface analysis, J. Mol. Struct. 1111 (2016) 76-83.

[75] R.S. Corrêa, M.H. dos Santos, T.J. Nagem, J. Ellena, Host-guest interactions between xanthones and water: the role of $\mathrm{O}-\mathrm{H} \cdots \mathrm{O}, \mathrm{C}-\mathrm{H} \cdots \mathrm{O}$, and $\pi-\pi$ contacts in the channeland cage-type frameworks, Struct. Chem. 23 (2012) 1809-1818.

[76] O. Estévez-Hernández, F.F. Salomón, J. Duque, J. Rodríguez-Hernández, D.M. Gil, Synthesis, structural and spectroscopic studies of 1-(2-furoyl)-3-phenylthiourea: a theoretical and experimental approach, J. Sulfur Chem. (2016) 1-25. 